\title{
İSLAM/TÜRK DEVLET VE TOPLUM GELENEĞİNDE RENKLER VE ANLAMLARI
}

\begin{abstract}
Ahmet KÜTÜK*
ÖZ

Birçok İslam ve Türk devletlerinde renkler, politik ve toplumsal bir temsil unsuru olarak kullanılmıştır. Kaynaklar, dikkatle incelendiği zaman görülecektir ki, İslam ve Türk geleneğinde renkler, çoğu zaman keyfi ve rastgele olmanın dışında bilakis devletin ve o devlete bağlı toplumun bir şekilde aidiyet ve sembol unsuru olarak kullanılmıştır. Spesifik bir konu olması ve tarihi kaynaklarda dağınık bulunması sebebiyle, İslam/Türk devlet ve toplumlarında köklü bir geleneği ifade eden bu konu pek incelenmemiş veya yalnızca siyasi anlamları üzerinde durulmuştur. Oysaki İslam/Türk toplumlarında renklerin yeri geldikçe sosyal, dini ve fikri anlamları da olduğunu, bazen bir iletişim aracı olarak, bazen de yas, sevinç, samimiyet duygularını ifade etmek için kullanıldığını, uğur ya da uğursuzluk addedildiğini görmekteyiz. Bugün renklerle ilgili birçok alışkanlıklarımıza da temel teşkil etmesi bakımından bu tarihsel geleneğin aydınlatılması önem taşımaktadır. $\mathrm{Bu}$ makalede, kaynaklar ışı̆̆ında, İslam/Türk devlet ve toplum anlayışında renklerin ifade ettiği siyasi, toplumsal, manevi ve temsili anlamları üzerinde durulacaktır.
\end{abstract}

Anahtar Kelimeler: Renk, İslam devletleri, Emeviler, Abbasiler, Selçuklular, Eyyubiler, Osmanlılar.

* Yrd. Doç. Dr., Mardin Artuklu Üniversitesi, Edebiyat Fakültesi, Tarih Bölümü, ahmetkutuk63@gmail.com 


\title{
COLOURS AND THEIR MEANINGS IN THE CUSTOMS OF ISLAMIC/TURKISH STATE AND SOCIETY
}

\begin{abstract}
In all the Islamic and Turkish states and societies, colours have a special significance. When the sources are analyzed, we see that colours, in Islamic and Turkish state traditions, are generally used as symbolic element and are not simply arbitary. Because of being a specific matter and existing in a range of scattered historical sources, this topic, which has a long tradition in Islamic/Turkish state and society, hasn't been emphasized enough and then only in political meanings. However we see that colours have in places social and intellectual meanings, even used as a communication tool. It is important to clarify this historical tradition because many of our habits about colours today are based on these. So, in this article I touch on the political, social, spiritual and representative meanings of colours in Islamic/Turkish states and socities in the light of the sources.
\end{abstract}

Key Words: Colour, Islamic states, Umayyads, Abbasids, Saljukids, Ayyubids, Ottomans. 


\section{GİRİŞ}

Her toplumda olduğu gibi İslam/Türk toplumlarında da gelenekler, geçmişten geleceğe kurulan bir köprüdür ve bir nevi yaşayış biçimi mirasıdır. Dolayısıyla diğer bütün konularda olduğu gibi, çağdaş toplumlarda renklerin ifade ettikleri manaların kökeninin de geçmişe dayandığı söylenebilir. Örneğin, yas tuttuğumuz zaman niçin siyahlar giyeriz, beyaz bayrak neden teslimiyet alametidir, kırmızı renk, kişiler ve toplumlararası iletişimde neden alarm durumu ifade eder? Bütün bu soruların cevabını tarihte, milletlerin geleneğinde, kültüründe ve egemenlik anlayışında aramak zorundayız. İslam/Türk devlet geleneği ve toplum yapısı içerisinde renk kavramını doğru anlayabilmek için de evvela onların münasebette bulunduğu toplum ve kültürler dönemin siyasi, dini ve toplumsal durumu göz önünde bulundurularak incelenmelidir. Bu bağlamda öncelikle bu tercihlerde belirleyici olan din unsuru (İslamiyet) ve onun ortaya koyduğu kültür ve medeniyet ele alınmalıdır ${ }^{1}$. Bunun yanında özellikle bedevi ya da göçebeler arasında yayılma ve genişleme imkânı bulan heteredoks inançlar, tarikatlar ve muhtelif fikir hareketlerinin benimseyip şiar edindikleri renkler de köken açısından ele alınmalıdır.

Tarihin her aşamasında görülüyor ki; çeşitli devletlerin, dini ve siyasi fırkaların kendilerine ait renk renk bayrakları olduğu gibi askerî, mülkî ve ruhanî rütbe ve sınıfların da ayrı ayrı renkleri vardır ${ }^{2}$. Genellikle hükümdarı ve saltanatı temsil eden bayrak, elbise, tıraz, çetr (hükümdar şemsiyesi) gibi hâkimiyet alameti olarak kabul edilen unsurların renkleri, sembolik bir anlam içermektedir. Çok eski menşeli olan ve daha ilk zaman devletlerinde görülen renklerin bu önemi, özellikle Ortaçağ İslam ve Türk devletlerinde de belirgindir ${ }^{3}$. Bir sembol aracı (alamet-i farika) olarak renk seçimi bazen devletin başındaki kişilerin şahsi tercihlerinden de etkilenmekteydi. Bu kişilerin, bu renkleri tercih ederken hangi hâlet-i ruhiye içerisinde bulundukları bilinemeyeceğinden tercih sebepleriyle ilgili çok fazla şey söylenemez. Fakat bu nevi kişisel tercihler, İslam/Türk toplumları için çok nadiren gerçekleşmiştir. Renkler genellikle dinî, siyasi, mezhepsel ya da ideolojik mensubiyet ifade ettiğinden rastgele tercih edilmezdi.

\footnotetext{
${ }^{1}$ M. Fuad Köprülü, “Bayrak”, İslam Ansiklopedisi,(IA),C. II, MEB Yayınevi, Eskişehir, 1977, s. 405.

${ }^{2}$ Şerafeddin Yaltkaya, “Tarihte Renk”, Türkiyat Mecmuası, C. VII-VIII, İstanbul, 1942, s. 43.

3 W. Barthold, İslam Medeniyeti Tarihi,(Başlangıç, İzah ve Düzeltmeler M. Fuad Köprülü), Diyanet Yayınları, Ankara, 1977, s. 174.
} 
İslamiyet öncesi devlet ve toplum örgütlenme biçiminde de renklere yüklenen anlamlar vardı: Mesela, Sasani ordusu düşmana hücuma kalkacağı zaman ateş renginde (kırmızı) bir bayrak çekiyordu. Siyasi anlamda da genellikle her devlet ya da kabilenin kendine özgü bir bayrağı ve bu bayrağı sembolize eden bir rengi olurdu. Firdevsî, Şehnâme'sinde efsanevi İran krallarının bayrakları konusunda menekşe rengine vurgu yapar ${ }^{5}$. İslam öncesi cahiliye toplumunun renkler ile münasebetleri hakkında çok bilgi olmamakla birlikte kabile esasına dayanan bu hiyerarşik düzende her kabilenin bir bayrağı olduğu ve her bayrağın rengi ile diğer kabilelerin bayraklarından ayrıldığı bilinmektedir. Kabileler bayraklarını mızrağın ucuna bağlar ve bu harpte bayraklar bizzat kumandan tarafından taşınırdı ${ }^{6}$. $\mathrm{Bu}$ bayrakların renkleri hakkında fazla bir bilgi mevcut değildir. Bununla birlikte, Cahiliye devrinde Karakuş adı verilen siyah renkli bir bayrağın mevcut olduğu bilinmektedir?

\section{HZ. PEYGAMBER, DÖRT HALIFE, EMEVİ VE ABBASİ DEVLETLERI DÖNEMINDE RENK GELENEĞİ}

Asr-1 Saadet döneminde Hz. Peygamber'in Ukab adı verilen siyah renkli bir bayrağı vardı. Belazurî, Hz. Ebubekir döneminde Halid b. Velid'in, Şam seferi sırasında fethettiği es-Seniyye adı verilen bölgeye Hz. Peygamber'e ait $U k a b$ adı verilen siyah renkli sancağı diktiğinden bahseder ${ }^{8}$. Hz. Peygamber'in sancağının beyaz renkli olduğu da rivayet edilirse de siyah olsa gerektir9. Her iki rengin ayrı sancaklarda kullanıldığı da vâki olabilir. Nitekim Bedir Savaşı'nda Müslümanların biri beyaz, diğer ikisi siyah renkli olmak üzere üç sancakları vardı. Beyaz sancak, Hz. Peygamber tarafından sahabenin önde gelenlerinden Mus'ab b. Umeyr'e, diğer iki sancaklardan birisi Hz. Ali'ye verilmiştir. Karakuş adı verilen ikinci siyah

\footnotetext{
4 Köprülü, "Bayrak", İA, II, s. 403. Savaş anında hücuma kalkarken kırmızı bayrak kullanılması kırmızı rengin iletişimde bir alarm durumu ve aciliyet ifade ettiğini açıkça gösteriyor. Kırmızının sonraki devletlerde aynı anlamı ifade ettiğini, hatta Osmanlı Devleti'nin de savaşta kırmızı bayrak çektiğini aşağıda türlü vesilelerle göreceğiz.

${ }^{5}$ Firdevsî, Şahnâme, (Çev. N. Lugal), Kabalcı Yayınevi, İstanbul, 2005, s. 530, 579, 651, 971 vd.

6 “Alem” İslam Ansiklopedisi, C. I, Eskişehir, 1997, s. 297-298; Köprülü, "Bayrak”, İA, II, s. 405.

${ }^{7}$ Corci Zeydan, İslam Medeniyeti Tarihi, (çev. N. Gök), İletişim Yayınları, İstanbul, 2004, s. 235. Karakuş ismindeki bayrak daha sonra Müslümanlar tarafından da aynı isimle kullanıldı. ${ }^{8}$ el-Belazurî, Fütuhu'l Büldan, (çev. M. Fayda), Kültür Bakanlığı Yayınları, Ankara, 2002, s. 162.

9 Zeydan, a.g.e., s. 235; İ. Hakkı Uzunçarşı1lı, Osmanlı Devlet Teşkilatına Medhal, TTK Yayınevi, Ankara, 1988, s. 71; “Alem” IA, I, s. 298.
} 
sancak ise Hz. Ayşe'nin çarşafından yapılmış olup ensardan birine verilmiştir $^{10}$. Ayrıca, Hz. Peygamber döneminde sarı renk bayrakların da kullanıldığına dair rivayetler vardır ${ }^{11}$. Vakanüvis Vasıf Efendi, bu dönemde sancaklar ve renkleri ile ilgili olarak şu kayıtları düşer:

Asr-ı Saadet'te çalgı yoktu. Lakin bayrak vardı. Hicretin beşinci senesi Şam'dan gelen kafile-i Kureyş ki reisi Ebu Cehil olup ǚ̧ yüz neferden ibaretti. Bunlar maiyetine otuz nefer muhacirin tayin buyrularak Resul-i Ekrem Efendimiz (s.a.v.) mübarek elleriyle bir mizrăga beyaz bir liva akdedüp Ebu Murted yedine vermiş ve Hamza $b$. Abdülmuttalib'i bu seriyyeye serdar tayin ve irsal buyurmuşlardı. Hayber Gazası'na kadar Müslümanlar sancaklarında beyaz rengi kullanmış, Hayber Gazasi'nda ise $R a^{\prime}$ yet denilen büyük ve siyah renkli bir sancak kullanılmıştır ${ }^{12}$.

İslam dünyasında Hz. Osman döneminde ortaya çıkmaya başlayan siyasi ayrılıklar, haliyle sancak ve bayrakların renklerine de kati derecede tesir etmiştir. Bu bağlamda, renkler aracılığıyla ifade edilmek istenen siyasi rekabet daha da güçlü bir boyut kazanmıştır. Bu dönemden itibaren ortaya çıkan siyasi fırka ve gruplar, belirlediği renkler aracılığıyla toplumda açıkça biz diğerlerinden farklıyız mesajını vermeye çalışıyorlardı. Böylece sonraki İslam devletlerinde, döneme göre değişen farklı renkte bayraklar kullanılmıştır. Dahası, özellikle bu dönemde tercih ettikleri renklere göre isimlendirilen siyasi grup ve hareketler var olmuştur. Örneğin, Abbasilerin siyah rengi kullanmalarından dolayı onlara Müsevvide (kökü sevd = siyah), onlara karşı çıkan ve Mukanna isyanıyla doruk noktasına ulaşan harekete mensup olanlara Mübeyyiza (kökü beyza = beyaz), Medya'da ortaya çıkmış olan bazı asilerin temsil ettikleri Muhammire (kökü Hamr = kırmızı) gibi ${ }^{13}$.

Emevi ve Abbasi devletleri döneminde daha da derinleşen mezhep kavgaları, renklere verilen sembolik anlamları belirginleştirerek ön plana çıkardı. Bunlardan ilki Emevilerin, siyasi hâkimiyetleri için beyaz rengi

\footnotetext{
${ }^{10}$ Zeydan, a.g.e., s. 234; Uzunçarş1l1, a.g.e., s. 2, not. 2; A. H. De Groot, "Sandjak-1 Sherif", Encyclopedia of Islam², vol. IX, Leiden, 1997, s. 14.

${ }^{11}$ Bkz. Yaltkaya, "a.g.m.", s. 43.

${ }^{12}$ Vasıf Efendi'den nakleden Zeki Pakalın, “Alem” Osmanlı Tarih Deyimleri ve Terimleri Sözlüğ̈̈, (OTDTS ), MEB Yayınevi, İstanbul, 1993, C. I, s. 47.

13 İbn Haldun, Mukaddime, (çev. S. Uludağ), C. I, Dergah Yayınları, İstanbul, 1988, s. 661; Zeydan, a.g.e., s. 235; Yaltkaya, “a.g.m.”, s. 43; J. Wellhausen, Arab Devleti ve Sükutu, (çev. F. Işıltan), Ankara Üniversitesi Basımevi, Ankara, 1963, s. 253; Köprülü, "Bayrak", İA, II, s. 405; Pakalın, “Alem” OTDTS, I, s. 47.
} 
sembolleştirmeleridir. Gerek İslam tarihi kaynakları, gerekse diğer kaynaklar Emevilerin hâkimiyet alameti olarak beyaz rengi kullandıkları konusunda hemfikirdirler ${ }^{14}$. Bununla birlikte, Emevilerin yeşil rengi de hâkimiyet sembolü olarak kullandıkları ve kırmızı sancakları bulunduğuna dair bilgiler vardır $^{15}$. Bu bağlamda İslam devletlerinde hâkimiyet sembolü olarak kullanılan renklerle sancak renklerinin farklı olabileceği sonucunu çıkarmak yanlış olmayacaktır ki, bu keyfiyetin diğer bazı devletlerde de vâki olduğunu aşağıda göreceğiz.

Emevilerin rakibi olarak onlarla mücadele etmek ve İslam dünyasının siyasi liderliğini ele geçirme iddiasıyla ortaya çıkan Abbas oğullarının hâkimiyet sembolü olarak belirledikleri renk, Emevilerden tamamıyla farklı ve zit olmalıydı ki; bu sebeple Abbasilerin siyah rengi seçmelerinden daha doğal bir şey olamazdı. Siyah renk, Abbasilerin ayırt edici alameti idi. Emevilere karşı daha ilk dönemlerde gerçekleştirilen dinî içerikli isyanlarda bu renk ön plana çıkmışt1 ${ }^{16}$.

Emevilerin Horasan valisi Kuteybe (öl. 715), "siyah elbiselilere" karşı bu bölgede mücadele etmek zorunda kald ${ }^{17}$. İbn Haldun'a göre Abbasiler, bu rengi Emeviler tarafından öldürülen Haşim oğulları şehitlerine matem işareti olmak üzere kabul etmişti ${ }^{18}$. Bazı kaynaklara göre ise, Huneyn Vakası'nda ve Mekke'nin fethi gününde Peygamberimiz, amcaları Abbas'a siyah bir bayrak vermişti. Abbasîler buna binaen siyaht tercih ettiler ${ }^{19}$. Başka bir rivayet, Abbasilerin, Kerbela şehidleri için hüzün ve matem alameti olarak siyah rengi tercih ettiği üzerinde durur ${ }^{20}$. Dahası, Arap antikitesinde siyah renk açıkça intikam anlamına gelmekteydi. Eski Araplar, intikam almak üzere ayaklandıklarında siyah sarık sararlardı ${ }^{21}$. Böylece, 750

\footnotetext{
${ }^{14}$ Wellhausen, a.g.e., s. 253; “Alem” İA, I, s. 298.

15 Yaltkaya, “a.g.m.”,s. 44; Zeydan, a.g.e., s. 235.

${ }^{16}$ Bernard Lewis, “Abbasids", Encyclopedia of Islam², vol. I, Leiden, 1986, s. 15-16.

${ }_{17}$ V. V. Barthold, Moğol İstilasına Kadar Türkistan, (Haz. H. D. Yıldız), TTK Yay., Ankara, 1990, s. 183; İbrahim Kafesoğlu, Türk Millî Kültürü, Boğaziçi Yayınları, İstanbul, 1984, s. 135.

18 İbn Haldun, I, s. 661; Zeydan, a.g.e., s. 235; Köprülü, "Bayrak”, İA, II, s. 405; Uzunçarş1lı, a.g.e., s. 2; Yaltkaya, “a.g.m.”, s. 44.

19 Yaltkaya, "a.g.m.", s. 44.

${ }^{20}$ Hamdullah Mustawfi-i Qazwinî, Ta'rikh-i Guzida, (Trans. E. G. Browne-R. A. Nicholson), E. J. W. Gibb Memorial, Leiden \& London, 1913, s. 56. Pakalın, “Alem” OTDTS, I, s. 47; "Alem" $\dot{I} A$, I, s. 298. Günümüzde Kerbela şehidlerini anma törenlerinde de siyahlar giyilmektedir.

${ }_{21}^{21}$ Wellhausen, a.g.e., s. 253; Yaltkaya, “a.g.m.”, s. 44. İbnu'1 Esir, 750 yllında Muhammed b. Halid b. Abdullah b. el-Kasri adlı kişinin siyahlar giyerek Emevilere isyan ettiğini yazıyor.
} 
yılında Zap suyu bölgesinde meydana gelen Emevi-Abbasi savaşı bir bakıma siyahın beyaza galip geldiği bir intikam savaşı olarak da görülebilir.

Abbasilerin siyah renkle olan münasebetleri, sadece bir sancak üzerine asılmıș olan bir bayrağın rengi olmaktan ibaret olmayıp onların bu rengi hâkimiyet sembolü olarak her alanda kullandıkları anlaşılmaktadır ${ }^{22}$. Bizzat halifeler, önemli bir sefer öncesinde siyahlar giydikleri gibi askerlerine de aynı renkleri giydiriyor, kendilerine manevi metbuiyeti tanıyan İslam devletlerine siyah renkte hâkimiyet alametleri (hilat, sarı, cübbe, çetr vs.) gönderiyorlardı. Mesela, Abbasi halifesi Kaim bi Emrillah (1031-1075), Besasiri üzerine sefere çıkmadan evvel siyah elbiselerini giymişti ${ }^{23}$. Aynı şekilde, el- Müsterşid Billah (1118-1135), Dübeys b. Sadaka üzerine sefere çıktığında siyah renkli cübbe, siyah sarık ve şal giyinmişti ${ }^{24}$. Yahudi seyyah Tudelalı Benjamin (öl. 1173), Bağdat gözlemlerini anlatırken halifenin Ramazan ayında bir alçakgönüllülük ifadesi olarak başında siyah örtü ile halkın arasına çıktığından bahseder ${ }^{25}$. Siyah renk, sonraları Abbasilere bağlı tüm Sünni devletlerin sembol rengi olmuştur. İbnu'l Cevzî, h. 462 (m. 10691070) yılı olaylarını anlatırken siyah rengin Sünnilerin bir simgesi olduğunu açıkça belirtir ${ }^{26}$.

Büyük İslam imparatorluklarında, hükümdarın resmi bayraklarından başka, türlü renk ve şekillerde bayraklar da kullanılırdı ${ }^{27}$. Bu bağlamda çok seyrek ve kısıtlı da olsa Abbasilerde beyaz rengin kullanıldığı görülmüştür. Nitekim Abbasi halifesi el-Mustansır Billah (1226-1242), hilafet makamına oturduğu 1226 yılında beyaz gömlek ve beyaz sarık giymişti ${ }^{28}$. Ayrıca, Abbasi yönetim anlayışında idari görev ve pozisyonlar, bazen farklı renkler tarafından temsil ediliyordu. Mesela, Abbasi halifesi el-Mütevekkil (847-

(İbnu'l Esir, el-Kamil fi't Tarih, (çev. Y. Apaydın), C. V, Bahar Yayınları, İstanbul, 1986, s. 332.)

22 el-Belazurî, s. 334; Köprülü, "Bayrak", İA, II, s. 405; Barthold, İslam Medeniyeti, s. 174.

${ }^{23}$ Mevdudî, Selçuklular Tarihi, (çev. A. Genceli), Hilal Yayınları, İstanbul, 1971, s. 203; Uzunçarşıl1, a.g.e., s. 2-3.

24 İbnu'l Esir, el-Kamil fi't Tarih, (çev. A. Özaydın), C. X, Bahar Yayınları, İstanbul, 1987, s. 481.

${ }^{25}$ Benjamin of Tudela, The Itinerary of Rabbı Benjamın of Tudela, (İng. Çev. A. Asher), vol. I, Hakesheth Publishing Co., New York ts., s. 97.

${ }^{26}$ Sibt İbnu'l Cevzî, Miratü'z Zaman fi Tarihi'l Ayan'da Selçuklular, (Seçme, Tercüme ve Değerlendirme Ali Sevim), TTK Yay., Ankara, 2011, s. 164.

${ }^{27}$ Köprülü, "Bayrak", İA, II, s. 405.

${ }^{28}$ İbnu'l Esir, el-Kamil fi't Tarih, (çev. A. Özaydın), C. XII, Bahar Yayınları, İstanbul, 1987, s. 420 . 
861) 850 yılında kendi oğullarını veliaht tayin ettiği zaman her birine iki sancak tevdi etmişti. Bunlardan biri veliahtll̆̆g ait siyah, diğeri valiliğe ait beyaz renkte sancaklard ${ }^{29}$.

Şiilerin kullandıkları renklerle ilgili olarak İslam kaynaklarında genellikle iki renkten bahsedilmektedir: Beyaz ve Yeşil ${ }^{30}$. Kaynaklardan anlaşıldığına göre, siyah ve beyazın birbirine olan zıtlığı, Emevi-Abbasi rekabetinde olduğu gibi, Şiiler tarafından da bir muhalefet ve rekabet aracı olarak kullanılmıştır. Abbasilerin politikalarından memnun olmayan Şiiler onların kullandıkları siyah renge mukabil beyaz rengi tercih etmişlerdir ${ }^{31}$. Özellikle, Abbasi Devleti'nin kuruluşunda büyük roller ifa eden Ebu Müslim el-Horasanî’nin 755 yılında yine Abbasiler tarafından idam edilmesi, önceleri siyah rengin ifade ettiği mazlumiyetin beyaz renk lehine dönüşmesine sebep olmuştur. Bu şekilde aşırı Şii hareketi olan Mübeyyiza (Sepid-Camegan) hareketi, Horasan ve Maveraünnehir'de ortaya çıarak Sunbad, Bih-Aferid, Mukanna gibi isyanlarla doruk noktasına ulaştı ${ }^{32}$. Böylece, Emevilere karşı siyah rengi kabul eden Abbasiler aleyhinde isyan edenler, onların siyah renklerine karşı beyaz bayrak ve elbiselerini giymekle ayaklandıklarını ilan ediyor ve bu sebeple de Mübeyyiza (Beyaz Elbiseliler) ismini alıyorlard1 ${ }^{33}$. Abbasilerin Horasan valisi Abdulcabbar'ın dahi 759 yılında halifeye karşı Mübeyyiza hareketi ile ittifak yaparak beyaz bayrak açtığı bilinir. Mübeyyiza hareketi, 12. asırda bile mevcuttu ve faaliyetleri uzun süre devam etti ${ }^{34}$.

Şiilerin yeşil rengi de belli bir yoğunlukta kullandıkları bilinmektedir ${ }^{35}$. Yukarıda adı geçen ve miladi 8 . yüzyıl son çeyreğinde peygamberlik iddiasıyla ortaya çıkan Mukanna (öl. 778?)'nın, şaşılığını gizlemek için yeşil renkli bir örtü kullandığı ve bu sebeple Mukanna (Örtülü)

\footnotetext{
${ }^{29}$ Zeydan, a.g.e., s. 234.

${ }^{30}$ Zeydan, a.g.e., s. 235; Yaltkaya, “a.g.m.”, s. 43; Wellhausen, a.g.e., s. 253. “Alem” İA, I, s. 298.

31 İbn Haldun, I, s. 661.

${ }^{32}$ Bu konuda bkz. Vasıf Efendi'den nakleden Pakalın, "Alem” OTDTS, I, s. 47; M. Fuad Köprülü, Türkiye Tarihi, Akçă̆ Yayınları, Ankara, 2005, s. 119, 121; Zeydan, a.g.e., s. 235; Barthold, Türkistan, s. 213; Osman Turan, Türk Cihan Hakimiyeti Mefkûresi Tarihi, C. I, Boğaziçi Yayınları, İstanbul, 1998, s. 139-140; amlf, Selçuklular ve Türk İslam Medeniyeti, Boğaziçi Yayınları, İstanbul, 1998, s. 457.

33 İbn Haldun, I, s. 661; Turan, Selçuklular ve Türk İslam Medeniyeti, s. 457.

${ }^{34}$ Barthold, Türkistan, s. 215.

${ }^{35}$ Köprülü, "Bayrak", IA, II, s. 405; Zeydan, a.g.e., s. 235; “Alem” IA, I, s. 298.
} 
ismini aldığı söylenir ${ }^{36}$. Yeşil rengin sadece Şiilerin çıkardığı isyanlarda değil, bazen bizzat Abbasi yönetimi tarafından muhtemelen yönetime muhalif Şiilerin gönlünü hoş tutmak için bir sembol olarak kullanıldığ 1 görülmektedir. Mesela Abbasi halifesi Me'mun (813-833), h. 204 (m. 819820) senesinde, Hz. Ali torunlarından Ali b. Musa el-Kazım'1 veliaht tayin ettiği zaman askere siyah elbiseyi çıkarıp yeşil elbise giymelerini emretmişti. $\mathrm{Bu}$ şekilde, sekiz gün boyunca Abbas oğulları ordusu ve Horasan reisleri bu yeşil elbiseleri giyinmiş, Nahrevan'dan Bağdat'a gidilmişti. Ancak söz konusu halife, bu biatten dönmek zorunda kalınca siyaha geri dönmeye de mecbur oldu ${ }^{37}$.

Abbasiler devrinde merkezi idareye karşı isyan çıkaranlar da genellikle egemen siyasi unsurun renklerine zit renkte bayraklar kullanmışlardır ${ }^{38}$. İbnu'l Esir, henüz Abbasilerin kuruluş y1lı olan m. 750 senesinde el-Cezire halkının beyazlar giyinerek Abbasi halifesi es-Saffah'a karşı isyan ettiklerini yazar. İsyancıların, Harran üzerine yürüyerek burayı kuşattıklarını, bu sebeple Saffah'ın bölgeye kardeşi Ebu Cafer'i göndermek zorunda kaldığını, Ebu Cafer'in halkı beyaz elbiseler giymiş olan Rakka ve Karkisya'dan geçtiğini ve aynı yıl Şam halkının da beyazlarla isyan ettiğini anlatır ${ }^{39}$.

Sonraki dönemlerde beyaz elbise giyme, Abbasilere karşı muhalif bütün hareketlerin ilk etapta başvurdukları bir hareket haline gelmiştir. Mesela Karmatiler de muhalif bir hareket olarak beyaz rengi seçmişlerdi ${ }^{40}$. Aynı şekilde bir Şii devleti olarak Fatımileri de beyazı tercih edenler arasında düşünmek gerekir ${ }^{41}$. İbnu'l Esir'in kaydettiğine göre, Alâeddin Ebu'l Ganaim b. El-Muhalleban adı verilen kişi m. 1056-1057 yılında Vasıt'ta beyaz elbise giymek suretiyle isyan etmiş ve hutbeyi Misır Fatımileri adına okutmuştu ${ }^{42}$. Yine Abbasi devletine karşı m. 1058 senesinde isyan ederek beyaz sancaklarla Bağdat'a yürüyen Arslan Besasiri de Fatımi

36 Barthold, Türkistan, s. 215; Mustafa Öz, "Mukanna el-Horasân̂̂”, Diyanet İslam Ansiklopedisi,(DIA), C. 31, Diyanet Yayınları, İstanbul, 2006, s. 124.

37 İbn Haldun, I, s. 661; Mustawfi, s. 61; Ahmet Cevdet Paşa, Kısas-ı Enbiya ve Tevarih-i Hulefa, (sad. A. Arslan) C. II, İstanbul, 1981, s. 67; Vasıf Efendi”den nakleden Pakalın, "Alem" OTDTS, I, s. 47; Zeydan, a.g.e., s. 235; Barthold, İslam Medeniyeti, s. 45.

${ }^{38}$ Köprülü, "Bayrak", IA, II, s. 405.

39 İbnu'l Esir, V, s. 352. Ayrıca bkz. Yaltkaya, “a.g.m.”, s. 44, not 1.

${ }^{40}$ İbn Haldun, I, s. 661.

${ }^{41}$ Uzunçarşıl1, a.g.e., s. 2, not. 2; Barthold, İslam Medeniyeti, s.174.

42 İbnu'l Esir, el-Kamil fi't Tarih, (çev. A. Özaydın), C. IX, Bahar Yayınları, İstanbul, 1987, s. 473. 
devleti adına hutbe okutmuştu ${ }^{43}$. Bunun yanında Fatımiler, sarı rengi imparatorluk rengi olarak kabul etmişlerdir ki onların halefleri olan Eyyubi ve Memlüklerin siyah sancaklar kullanmakla birlikte sarı renk geleneğini de devam ettirmiş olduklarını aşağıda göreceğiz ${ }^{44}$.

\section{ORTA ASYA TÜRK DEVLETLERINDE RENK GELENEĞİ}

İslamiyet kabul edilmeden önce Türklerin renklerle olan iletişimi nasıldı? İslam sonrası renklerle ilgili alışkanlıkları sağlıklı bir şekilde tespit etmek için öncelikle bu sorunun cevaplandırılması gerekir. Her şeyden evvel İslam öncesi Türk toplumlarının, renkleri salt siyasi sembol olarak değil, bazen bir toplumsal ya da mezhepsel aidiyetlerini göstermek için, bazen de bir iletişim vasıtası olarak kullandıklarını belirtmek gerekir. Renkler, Türk toplumları arasında şehir, dağ, deniz ve ova ve gölleri adlandırmada hatta yönleri ifade etmek maksadıyla da kullanılmıştır.

Türklerin tarihte göründüğ̈ ilk dönemlerden itibaren toplumsal ve askeri örgütlenme içerisinde önemli bir yer işgal eden atların genellikle renkleriyle (Boz, Doru, Ak, Yağız vs.) adlandırıldığını biliyoruz. Hun imparatoru Mete'nin, Çin'e gerçekleştirdiği bir kuşatmada atlarını renklerine göre dört tarafa yerleştirdiğine dair bir Çin belgesinde doğuda kır, güneyde doru, batıda ak, kuzeyde yağız atlar yer almışlardı şeklinde geçen ifade, eski Türklerde renklerin hem askeri yerleşimde, hem de yönleri ifade etmede kullanıldığını gösteriyor ${ }^{45}$. Göktürk ve Uygur devlet geleneğinde de çadırların renklerine bağlı bir hiyerarşik düzen kurulur, kağanlar Altın işlemeli otağda oturur ve kırmızı elbiseler giyerdi ${ }^{46}$.

İslamiyet öncesi Türklerin Göktanrı inancının etkisiyle gökyüzünün rengi olan mavi renge ayrı bir önem verdikleri anlaşıllyor. Bu itibarla Oğuz Destanı'nda geçen Oğuz Han bir gün Tanrı'ya ibadet ederken birdenbire ortalık karardı. Gökten mavi bir ışık düştü ${ }^{47}$ şeklindeki ifade, Oğuz Türklerinin bu renge bir kutsallık atfettiğini gösterir. Oğuzların genel olarak yünden ve beyaz (Türkçede ak) elbise giydikleri, kara rengi de uğursuzluk,

\footnotetext{
${ }^{43}$ Bkz. Turan, Selçuklular ve Türk Íslam Medeniyeti, s. 138.

${ }^{44}$ Bkz. Köprülü, "Bayrak", IA, II, s. 410. Beyaz rengin yanında Fatımi bayraklarının yeşil ya da kırmızı olabileceğine dair rivayetler vardır. Bkz. Yaltkaya, "a.g.m.”, s. 44.

${ }^{45}$ Sencer Divitçioğlu, Kök Türkler (Kut, Küç ve Ülüg), Ada Yayınları, İstanbul, 1987, s. 115.

${ }^{46}$ Bahaeddin Ögel, Türk Kültürünün Gelişme Çağları, C. II, MEB Yayınevi, İstanbul, 2001, s. 76.

${ }^{47}$ Köprülü, Türkiye Tarihi, s. 102.
} 
felaket ve yas alameti olarak kullandıkları söylenebilir ${ }^{48}$. Fakat siyasi anlamda aynı rengin Oğuzlar arasında verdiği intiba farklı olmuştur. Firdevsî’nin, İran-Turan mücadelelerinden bahsederken Türklerin ve Türk hükümdarı Efrasiyab'ın bayrağını siyah renkte göstermesi, sonraki Oğuzlar arasında siyah rengin yaygınlığı ve millî renk addedilmesi hususunu

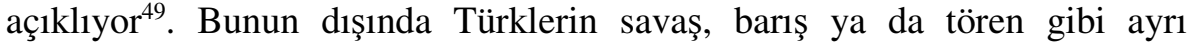
durumlarda ayrı anlamları ihtiva eden farklı renkte bayraklar kullandıkları da bilinmektedir ${ }^{50}$.

Horasan ve Maveraünnehir'den Çin'e doğru bir seyahat icra ederek çeşitli Türk kabilelerini gören İslam seyyahı Nasr b. Ahmed-i Samanî (913942) Oğuzların bayrağının siyah olduğunu belirtir ${ }^{51}$. 10. asır İslam seyyahı Ebu Dülef de dokuz oğuzların siyah bayrakları kullandıklarını kaydetmek suretiyle Oğuzlar arasında siyah rengin yaygınlığını teyit eder ${ }^{52}$. Kuşkusuz Oğuzlar, İslam dairesine girip Sünni Hanefi mezhebi kabul ettikten sonra Abbasi hilafetine manevi bağlll1kları sebebiyle, bu renge daha başka bir anlam yüklediler. Oğuz Türklerinin kırmızı renge de önem verdikleri Kaşgarlı Mahmud'un onların bayraklarını kırmızı renkten yaptıkları şeklindeki kayıtlarından anlaşılıyor ${ }^{53}$. Bunun yanında Oğuzların menekşe, sarı, kırmızı ve mavi renklerde bayraklar da kullandıklarına dair bilgiler $\operatorname{vardir}{ }^{54}$.

Nasr b. Ahmed-i Samanî, Orta Asya'nın bir diğer önemli Türk kitlesi olan Kırgızların bayrağının yeşil renkte olduğunu yazmaktadır ${ }^{55}$. Kırgızların yaşadığı coğrafyadan geçmiş olan Ebu Dülef de Kırgızların yeşil renkli bayraklar kullandıklarını belirtir ${ }^{56}$. Bununla birlikte, bilinen yeşil kelimesinin eski Türklerde aynı zamanda mavi renge de karşılık geldiğini Kutadgu

48 Faruk Sümer, "Oğuzlar”, İA, C. IX, MEB Yayınevi, Eskişehir, 1997, s. 381. Beyaz kelimesi, Arapça kökenli olup Türkçede bu anlamı karşılayan kelime ak kelimesidir. Şahıs, coğrafya, devlet, para adlandırmaları bu kelime üzerinden yapılırdı. (Ak-sungur, Ak-deniz, Ak-şehir, Ak-Koyunlu, Ak-ça vs.)

${ }^{49}$ Firdevsî, s. 243, 270; Köprülü, Türkiye Tarihi, s. 171; amlf., "Bayrak”, İA, II, s. 404.

${ }^{50}$ Ögel, a.g.e., II, s. 80-81.

${ }^{51}$ Ahmed Samanî'den aktaran Köprülü, Türkiye Tarihi, s. 133-134.

52 İbn Fazlan, İbn Fazlan Seyahatnâmesi, (2. Kısım Ebu Dülef Tercümesi), (Haz. R. Şeşen), Bedir Yayınevi, Ankara, 1975, s. 88; Köprülü, "Bayrak", IA, II, s. 404.

${ }^{53}$ Kaşgarlı Mahmud'dan aktaran Köprülü, "Bayrak”, İA, II, s. 401-402.

${ }^{54}$ Köprülü, "Bayrak", IAA, II, s. 404. Firdevsî de bir vesileyle Türk ordusunda kırmızı, sarı ve menekşe renkli bayraklardan söz eder. Bkz. Firdevsî, s. 913.

${ }^{55}$ Aktaran Köprülü, Türkiye Tarihi, s. 133-134.

${ }^{56}$ İbn Fazlan Seyahatnâmesi, (2. Kısım Ebu Dülef Tercümesi), s. 88; Köprülü, "Bayrak”, İA, II, s. 404. 
Bilig'de çok sık geçen "yağız yir-yaşıl kök” (yağız yer-mavi gök) söyleminden anlamak zor değildir ${ }^{57}$. Kırgızlarla ilgili olarak Çin kaynakları onların kırmızı renge hürmet ettiklerini söylemek suretiyle bu bayrakların kırmızı renkte olduğunu ima etmektedirler ${ }^{58}$. 13. asrın Çinli seyyahı Ç’ang Ç'un'un Uygur ülkesindeki Budist rahiplerin kırmızı elbiseler giydiklerine dair kaydından bu rengin Uygurlar arasında da yaygın olduğu anlaşılıyor ${ }^{59}$. Ayrıca Maniheistlerin genellikle beyaz giyinmelerinden bu dini kabul etmiş bir toplum olarak Uygurlar arasında beyaz rengin de yaygın olduğu sonucu çıkarılabilir ${ }^{60}$.

Moğol devri İslam müverrihleri, 12. ve 13. asırlarda Kıpçak kabilelerinin bayrakları bulunduğunu belirtirse de bunların ne renkte olduğuna değinmez. Hâlbuki daha önceleri batıya doğru ilerleyerek Ruslar ile birçok savaşlar yapan bir kısım Kıpçak-Kumanların kırmızı ve beyaz bayrakları olduğu meşhur İgor destanından anlaşılmaktadır ${ }^{61}$. Bizans kaynakları vasıtasıyla bildiğimiz Peçenek kabile isimlerindeki renge dalalet eden kelimelerin belki de bunların kullandıkları bayrakların renkleri dolayısıyla verilmiş olduğu düşüncesinden hareketle Peçeneklerin çeşitli renklerde bayraklar kullandıkları düşünülebilir. İbn Rusta, ne renk olduğunu söylemeksizin Hazarların da bayrakları olduğundan bahseder ${ }^{62}$.

Türk devlet ve toplumlarının renk seçimi, İslami gelenekten büyük ölçüde etkilenmiştir. Bununla birlikte renk geleneğinin, İslam öncesi alışkanlıklar sürdürülerek İslam sonrası dönemde daha zengin bir kompozisyon içerisinde devam ettirildiği söylenebilir. İlk Müslüman-Türk devletlerinden Gazneliler siyah rengi hâkimiyet alameti olarak kabul etmişlerdi. Gaznelilerde bayrağın yanısıra çetr, külah ve hil'at gibi birtakım hâkimiyet alametlerinin de siyah renkli olması, gerek Mahmud'un gerekse oğulları Muhammed ve Mesud'un saltanatları zamanında daima siyah renkte bayraklar kullanılması, bu rengin devlete mahsus resmi renk olduğunu kati suretle anlatmaktadır ${ }^{63}$.

\footnotetext{
57 Yusuf Has Hacib, Kutadgu Bilig, C. I, (Metin R. Rahmeti Arat), TDK Yayınları, Ankara, 1999, s. 17, 19, 21, 24, 26, 117 vd.

${ }^{58}$ Köprülü, "Bayrak", $\dot{I} A$, II, s. 404.

${ }^{59}$ Ç' ang Ç'un'dan naklen, Barthold, Türkistan, s. 413.

${ }^{60}$ Kafesoğlu, a.g.e., s. 128; L. Ligeti, Bilinmeyen İç Asya, (Çev. S. Karatay), C. II, MEB Yayınevi, İstanbul, 1991, s. 98.

${ }^{61}$ Köprülü, "Bayrak", İA, II, s. 404.

${ }^{62}$ Köprülü, "Bayrak", İA, II, s. 404.

${ }^{63}$ Köprülü, "Bayrak”, İA, II, s. 406; Aydın Taneri, “Çetr”, DİA, C. 8, Ankara, 1993, s. 293.
} 
Gaznelilerde sülalenin sembolü olarak siyah renk kabul edilmesinin sebebi, eski Türklerde bu rengin sembolik renk olmasından dolayı mıdır? Yoksa onların siyah rengi sembol kabul etmiş olan Abbasi halifeleri ile çok samimi münasebetlerde bulunmalarından ve tahta çıkan hükümdara Abbasi halifesinin menşur ile birlikte siyah hil' at ve bayrak göndermesinden dolayı midır? Bu konuda kesin bilgi yoktur. Yine de, Gazneli Devleti'nin takip ettiği İslami siyaset göz önüne alınınca ikinci ihtimal daha kuvvetli görünür, fakat birinci seçeneğin de bu hususta az çok tesiri olması ihtimali de yok değildir ${ }^{64}$. Bu dönemin müellifi Utbi'nin Türkleri tanımlarken sarf ettiği sözlerden, Gazneliler devrinde siyahın sadece devleti sembolize eden resmi renk olarak değil, aynı zamanda halk arasında da yaygın olduğu rahatlıkla anlaşılıyor: "Yüzleri geniş, gözleri küçük, burunları yassı, sakalları seyrektir. Demir kılıçlı ve siyah elbiselidirler." 65

Bir diğer ilk Müslüman Türk devleti olan Karahanlıların "Al” adını verdikleri turuncu renkte ipek işlemeli bir bayrağı hâkimiyet sembolü olarak kullandıkları bilinmektedir ${ }^{66}$. Onların kâfir Uygurlara karşı yaptığı gazalara dair Kaşgarlı Mahmud'da geçen bir şiirde: "Müslümanların al bayră̆ yükseldi. Kara toz göklere çıktı. Uğrak (kabile) süvarileri de bize gelip karıştı birlikte savaş yaptık" denmektedir ${ }^{67}$. Karahanlı Devleti'nde hükümdarın çetrinin de kırmızı renkli olmas ${ }^{68}$ ve Karahanlılar ailesinden Semerkant ve civarına hâkim olan Ali Tegin'in de kırmızı renkli bayrağa sahip bulunması onların bu rengi millî ve resmi addettiklerini açıkça gösterir. Kırmızı renk hükümdarın ve hanedanın bayrak ve çetrlerine mahsus olmakla beraber ayrıca başka renkte bayraklar kullanıldığı da tahmin olunabilir ${ }^{69}$. Bunun yanında Karahanlı devlet geleneğinde hakandan sonra yuğruş lakabını alan ve hanedana mensup olanlara bir siyah çetr verilir ve yaz kış başında tutulurdu ${ }^{70}$.

\footnotetext{
${ }^{64}$ Köprülü, "Bayrak", İA, II, s. 406.

${ }^{65}$ Utbi'den naklen, Barthold, Türkistan, s. 293.

${ }^{66}$ Köprülü, Türkiye Tarihi, s. 150; amlf., "Bayrak", IA, II, s. 401-402; Turan, Selçuklular ve Türk Íslam Medeniyeti, s. 55, not 8.

${ }^{67}$ Turan, Türk Cihan Hâkimiyeti, I, 160.

${ }^{68}$ Uzunçarş1l1, a.g.e., s. 29, not 1; Taneri, "Çetr", DİA, s. 293.

${ }^{69}$ Köprülü, "Bayrak", İA, II, s. 406-407; Barthold, Türkistan, s. 315.

${ }^{70}$ Köprülü, Türkiye Tarihi, s. 150; Köprülü, "Bayrak”, İA, II, s. 407.
} 


\section{SELÇUKLU DEVLETLERINDE RENK GELENEĞİ}

İslam dünyasının zor bir dönem geçirdiği süreçte ortaya çıkan ve Sünni-Hanefi İslam'ın siyasi iktidarını güçlü bir şekilde temsil eden Selçuklu Türkleri, maneviyatta her yönüyle Abbasi hilafetine bağlıydı. Bu sebeple Selçuklular, Abbasilerin hâkimiyet sembolleri olan siyah rengi her yerde temsil etmiş ve bizzat Selçuklu sultanları onlara bağlılığın bir göstergesi olarak bu renkte elbiseler giymişlerdi. İlk Selçuklu sultanı Tuğrul Bey, Bağdat'a geldiğinde kendisine yedi siyah cübbe giydirilip başına da siyah emame sarılarak halife huzuruna çıkmıştır ${ }^{71}$. Türk devlet geleneğinde sultanların hâkimiyet sembolü olarak önemli bir yer tutan çetr (hükümdar şemsiyesi) de genellikle siyahtı ve Abbasilere olan sadakatin işaretiydi ${ }^{72}$. Büyük Selçuklu sultanı Tuğrul Bey başlangıçta kırmızı renkli çetr kullanmıştı. Sonraları halife ile ilişkiler neticesinde bu renk siyaha dönüşmüş olmalıdır. Sultan Melikşah da Emir el Ümera ünvanlı amcası Osman b. Davud'a siyah bir çetr (çetr el-esved) vermişti ${ }^{73}$.

Çok nadir olmakla birlikte, Abbasilerle ilişkilerin bozulduğu dönemlerde bir tepki ya da protesto bağlamında bu siyah elbiselerin çıkartıldığını görüyoruz. Tuğrul Bey’in, halifenin kızına talip olması ve halifenin de bunu reddetmesi üzerine dönemin Selçuklu veziri Amidü'l Mülk'ün Nahrevan mevkiindeyken çadır kurup siyah Abbasi sarığını çıkarıp beyaz Türk sarık ve elbiselerini giymesi bu anlamda manidardır ve kayda şayandır ${ }^{74}$.

Selçuklu vezirinin, bu şekilde siyahı çıkarıp beyazlar giyinmesi Selçuklu devlet geleneğinde beyaz renge de önem verildiğini, yeri geldikçe bir hâkimiyet alameti olarak kullanıldığını gösterir. İbnu'l Esir, Tuğrul Bey'in kişiliğini anlattığı bir metinde onun beyaz elbiseler giyme alışkanlığından bahseder ${ }^{75}$. Tuğrul Bey'in halefi sultan Alp Arslan da Malazgirt savaşına çıkmadan önce baştan aşağı beyazlara bürünmüştü.

\footnotetext{
${ }^{71}$ Köprülü, Türkiye Tarihi, s. 171, 206, not 111; Uzunçarş11, a.g.e., s. 3; V. Gordlevski, Anadolu Selçuklu Devleti, (çev. A. Yaran), Onur Yayınları, Ankara, 1988, s. 149, 273; Barthold, Islam Medeniyeti, s. 174.

${ }^{72}$ Uzunçarşıllı, a.g.e., s. 71; Claude Cahen, Osmanlılardan Önce Anadolu,Tarih Vakfı Yurt Yayınları, Ankara, 2002, s. 178; Turan, Selçuklular ve Türk Íslam Medeniyeti, s. 201. Cahen'e göre bu Çetr, hükümdarın kendi malı sayılıp öldükten sonra mezarlarına konurdu. (Bkz. Cahen, a.g.e., s. 178.)

${ }^{73}$ Bkz. Uzunçarş1l1, a.g.e., s. 28-29; Erdoğan Merçil, Selçuklular'da Hükümdarlık Alâmetleri, TTK Yayınları, Ankara, 2007, s. 104, 114.

${ }^{74}$ Mevdudî, a.g.e., s. 209.

75 İbnu'l Esir, X, s. 43.
} 
Anadolu'nun tarihini değiştiren bu önemli savaş öncesinde beyaz giyilmesinin, ayrıca samimi niyet, masumiyet, saflık ve içtenlik anlamına geldiğini Alp Arslan'ın askerlerine sarf ettiği şu sözlerden anlamak güç değildir: "Ey askerlerim eğer şehid olursam bu beyaz elbise kefenim olsun, o zaman ruhum göklere çıkacaktır. Benden sonra Melikşah'ı tahta çıkarınız ve ona bağlı kalınız. Zaferi kazanırsak istikbal bizimdir"76.

İlk dönem Selçuklu sultanlarının bayraklarda ağırlıklı olarak siyah rengi tercih ettiği görülür. Selçuklu reisleri Tuğrul, Çağrı Beyler ile Musa Yabgu, daha 1039 yılında Gazneli Mesud ile savaşırken siyah sancaklar taşımışlardı ${ }^{77}$. Bu gelenek, sonraki Selçuklu sultanları tarafından da sürdürüldü. Öyle ki; Büyük Selçukluların son sultanı Sancar, kendisine tabi devletlerin dahi hâkimiyet alameti olarak farklı renkler kullanmasını hoş karşılamıyordu. Sancar, Irak Selçuklu sultanı Mahmud ile yaptığı bir anlaşmada onun kendi kızıl rengini bırakıp Sultan Sancar'ın beyaz ve siyah renklerini kullanmasını istiyordu ${ }^{78}$. Keza, Emir Gazi'nin Haçlılara ve Ermenilere karşı kazandığı muvaffakiyetlerden sonra kendisine Halife ve Sultan Sancar tarafından bir elçi ile dört siyah bayrak kapısında çalınmak üzere davul vs. gönderilmişti ${ }^{79}$. Bununla birlikte ilginç bir ayrıntı olarak Selçuklu ordusunun 100 bin kişiden fazla miktarda toplandığı zamanlarda halifeden farklı olması maksadıyla bayrağın siyah değil kızıl, yeşil ve sarı renklerden oluştuğu görülmektedir ${ }^{80}$.

Anadolu Selçuklu Devleti'ne gelince: Abbasi hilafetini tanıyan bir devlet olarak Anadolu Selçuklularının da siyah renk sancak tercih etmeleri mukadderdi. İbn Bibî, I. Alâeddin'in Kâhta'yı ele geçirmesi bahsinde sultan sancağının siyah renkli (drafş-i siyah) olduğunu açıkça belirtiyor ${ }^{81}$. Ayrıca Selçuknâmelerde hükümdar şemsiyesi için Ukab-ı Çetr-i Hümayun tabirinin

\footnotetext{
76 İbnu'l Esir, X, s. 72; Mevdudî, a.g.e., s. 242;Turan, Türk Cihan Hâkimiyeti, I, s. 192; Turan, Selçuklular ve Türk İslam Medeniyeti, s. 182. Beyaz renk, genel olarak İslam toplumlarında da temizlik saflık ve samimiyeti karşılamaktadır. Ata Melik Cüveynî, Otrar faciası öncesinde Moğolların Müslümanlara saygı göstererek Müslüman oldukları için onlara beyaz ve temiz keçeden çadırlar kurduklarını yazıyor. Bkz. Alaaddin Ata Melik Cüveynî, Tarih-i Cihangüşa, (Çev. M. Öztürk), C. I, s. Ankara, 1988, s. 136.

${ }^{77}$ Merçil, a.g.e., s. 123, 139.

${ }^{78}$ Turan, Selçuklular ve Türk İslam Medeniyeti, s. 237; Merçil, a.g.e., s. 139.

${ }^{79}$ Osman Turan, Selçuklular Zamanında Türkiye, İstanbul, 1996, s. 172.

${ }^{80}$ Turan, Selçuklular ve Türk İslam Medeniyeti, s. 237.

${ }^{81}$ İbn Bibî, el- Hüseyin b. Muhammed b. Ali el-Caferi er-Rugadi, el-Evâmirü'l-Alâ'iyye fi'l Umuri'l-Ala'iyye, (Selçuknâme), (çev. M. Öztürk), II Tercüme, TTK Yayınları, Ankara, 2014, s. 300; Uzunçarş1ll, a.g.e., s. 73; Merçil, a.g.e., s. 133.
} 
kullanılması da siyah rengin baskınlığını gösterir ${ }^{82}$. Abbasi halifesi Nasır li Dinillah (1180-1225) Selçuklu sultanı I. İzzeddin Keykavus'a hâkimiyet alameti olarak bir saltanat menşuru ile birlikte siyah bir imame zırhlı elbise göndermişti. Adı geçen sultan öldüğünde parmağındaki yüzüğü dahi siyahtı ki, o sırada kendisi tarafından Malatya'da hapsedilmiş olan Alâeddin Keykubad'1 İzzeddin'in öldügüne ikna etmek için ona bu siyah yüzük gösterilmişti ${ }^{83}$.

I. Alâeddin Keykubad, Harput'u ele geçirdikten sonra oradaki Eyyubi ümerasına kendisine itaatin bir göstergesi olarak giymeleri için siyah hil'atler göndermiş ve onları ziyafete davet etmişti ${ }^{84}$. Aynı sultanın, 1230 yılında amcazadesi Cihanşah'ın elinden Erzurum'u alması ile ilgili bahiste İbn Bibî'nin sultanın ordusuyla ilgili olarak Güneş gibi siyah çetr harekete geçti; ordu dă̆a ve ovaya doğru ilerledi şeklindeki şiirinden de çetrin siyah olduğu anlaşılmaktadır. Müellif, sonraki dönemde Saadettin Köpek'in kendi ihtirasları için II. Gıyaseddin Keyhüsrev'i kandırarak siyah renkli çetr'i maviye çevirttiğini kaydediyor ${ }^{85}$. Bu tercih Abbasi halifeliğince bir düşmanlık alameti gibi karşılanmıştı. Hükümdara mahsus çetr ile bayrağın aynı renkte olması ortaçağda umumi bir kaide olduğu için saltanat sancağının da maviye çevrilmiş olması, icap ederse de kaynaklarda bu durum doğrulanmıyor. Nitekim bu mavi rengin Saadeddin'in katlinden sonra veya başka bir zamanda tekrar kaldırılıp kaldırılmadığı da kaydedilmiyor. Her ne olursa olsun, bu örnekler Anadolu Selçuklularında siyah renk kullanma geleneğinin Abbasilere bağlılıklarını göstermek maksadıyla sürdürüldüğünü göstermektedir ${ }^{86}$.

Anadolu Selçuklu devrine ait kaynaklarda hükümdarın resmi sancağından başka yarı müstakil beyliklere, büyük ricale, kumandanlara ve askeri kıtalara mahsus bayraklar bulunduğu, ordudaki bayrakların sarı ve kırmızı renklerde olduğu zikredilmektedir. Anadolu Selçuklularının Moğolları taklit ederek bayraklarında beyaz rengi kabul ettiklerine dair iddialar yanlış olmakla birlikte, Moğol tahakkümü altında bağımsızlığını

\footnotetext{
${ }^{82}$ Uzunçarşı1l, a.g.e., s. 71; Merçil, a.g.e., s. 113. Yukarıda bahsedildiği üzere Ukab, Hz. Peygamber' in bayrağının adıydı ve siyah renkte idi.

${ }^{83}$ Bkz. İbn Bibî, s. 230;Turan, Selçuklular Zamanında Türkiye, s. 298, 327; Uzunçarş1l1, a.g.e., s. 64 .

84 İbn Bibî, s. 432. Müellif, sultanın ziyafette bu Şam ümerasından olan Şemseddin Savab adlı kişinin bu siyah hil'ati giymediğini görünce hiddetlendiğini de ekliyor. Bkz. Aynı Yer.

85 İbn Bibî, s. 402, 458; Uzunçarşıll, a.g.e., s. 71; Merçil, a.g.e., s. 114.

${ }^{86}$ Köprülü, "Bayrak", IAA, II, s. 408-409; Uzunçarşılı, a.g.e., s. 71; Taneri, “Çetr”, DİA, s. 294.
} 
kaybeden bir devlet olarak onların İlhanlı bayraklarını da Selçuklu bayrakları ile beraber kullanılması doğal karşılanmalıdır ${ }^{87}$.

Selçuklu sultanları, kırmızı rengi de ayırıcı bir saltanat alameti olarak kullanmaktaydılar. Bazı Türk devletlerinde bayrak rengi olarak da kırmızı renk tercih edilmekteydi. Büyük Selçuklu sultanı Tuğrul Bey, 1038 yılında Nişabur'a girdiğinde başında kırmızı renkli ipekli kumaştan yapılmış bulunmaktayd ${ }^{88}$. Müverrih Ravendî de 1161 yılında Abhaz meliki üzerine yapılan sefer vesilesiyle Irak Selçuklu hükümdarı Arslan b. Tuğrul'un ordusundaki kırmızı ipekten bayraklardan bahsetmektedir ${ }^{89}$. Esasen bu rengin Karahanlılarda resmi renk olduğu gibi bazı Türk kabileleri arasında da mukaddes renk telakki edildiğini düşünürsek bu kırmızı renkli bayrakların menşei meselesi daha iyi anlaşılır ${ }^{90}$. Hükümdarların ayaklarına giydikleri kırmızı çizme veya edikler ve hükümdar seraperdesi denilen büyük ve odalı çadırın rengi de kırmızı olurdu ${ }^{91}$.

İbn Bibî’nin, I. Gıyaseddin Keyhüsrev'in ölümüyle sonuçlanan 1211 yılındaki Alaşehir Muharebesi'ni anlatırken adı geçen sultanın kırmızı kaftanını giyinmiş olarak ordunun merkezinde bulunduğuna dair kaydı ${ }^{92}$; I. Alâeddin Keykubad'ın 1220 senesinde Venediklilerle imzaladığı anlaşmada kırmızı renkli tuğrasını ihtiva eden imzasını kullanmas $1^{93}$ ve sahte Selçuklu sultanı olarak bilinen Alâeddin Siyavuş (Cimri)'un, Selçuklu ordusu ile yaptığı muharebeyi kaybettikten sonra savaş meydanında sultanlara mahsus kırmızı çizmelerinden tanınarak yakalanması gibi ayrıntılar düşünüldüğünde

\footnotetext{
${ }^{87}$ Köprülü, "Bayrak”, İA, II, s. 408-409.

${ }^{88}$ Merçil, a.g.e., s. 104.

${ }^{89}$ Ravendî, Râhat-üs-Südûr ve Âyet-üs Sürûr, (çev. A. Ateş), C. II, TTK Yayınları, Ankara, 1999, s. 275, 297.

${ }^{90}$ Köprülü, "Bayrak”, İA, II, s. 407-408; Uzunçarşılı, a.g.e., s. 28-29; Taneri, "Çetr”, DİA, s. 293. İslam öncesi Türk devletlerinde de kağanların kırmızı giymesi geleneği mevcuttu. İkinci Uygur kağanı Bayan Çur'u ziyaret eden bir Çin elçisi onun kırmızı bir elbise giymiş olduğunu bildirir. (Aktaran Ögel, a.g.e., II, s. 81) Bir Selçuknâme'ye göre, Malazgirt Savaşı'nda Bizans imparatoru Romen Diyojen (1068-1071) de kırmızı atlastan bir fistan giymişti. (Sadruddin Ebu'l Hasan Ali İbn Nasir İbn Ali el-Hüseyni, Ahbarü'd-Devleti's-Selçukiyye, (çev. N. Lugal), TTK Yayınları, Ankara, 1999, s. 34.

91 Uzunçarşılı, a.g.e., s. 29-30. Sultan Melikşah, askerler tarafından malı yağma edilen bir köylünün şikayeti üzerine ona kırmızı (kızıl) kubbe (çadır)'ye gidip beklemesini söylemişti. Bkz. Merçil, a.g.e., s. 208.

92 İbn Bibi, Selçuknâme, (çev. M. H. Yinanç), (Haz. R. Yinanç-Ö. Özkan), Kitabevi Yayınları, İstanbul, 2010, s. 39. Ayrıca bkz. amlf., (M. Öztürk), s. 137.

93 Osman Turan Türkiye Selçukluları Hakkında Resmi Vesikalar (Metin, Tercüme ve Araştırmalar), TTK Yayınevi, Ankara, 1988, s. 143-144; Merçil, a.g.e., s. 202.
} 
aynı keyfiyetin Anadolu Selçukluları için de geçerli olduğu ve kırmızı rengin saltanat alameti olarak kullanıldığı görülür ${ }^{94}$.

Son olarak Selçuklulara bağlı yarı bağımsız siyasi oluşumları temsil eden Atabeyliklerin de ordularında tıpkı Selçuklularda olduğu gibi muhtelif renk ve şekillerde türlü türlü bayraklar kullanıldığı muhakkaktır. Mesela, Oğuzların Salur boyuna mensup olan Salgurlular sülalesinden Sad b. Zengi'nin siyah renkli bayrağı olduğu bilinmektedir. Bu sancağın siyah renkli olması Harizmşahlarda olduğu gibi kendilerini Selçuklu imparatorluğunun meşru varisi saymalarından ileri geliyordu. Diğer atabeylerin de aynı maksatla bayraklarında ve çetrlerinde siyah rengi kabul etmiş olmaları kuvvetle tahmin olunabilir ${ }^{95}$.

\section{HARİZMŞAH, EYYUBİ, MOĞOL VE MEMLÜK DEVLETLERINNDE RENK GELENEĞİ}

Siyah renk, bir başka Türk devleti olan Harizmşahlar için de hâkimiyet sembolü olarak kullanılmıştır. Celaleddin'in sultanlık alameti olan çetr, bayrak ve tırazı hep siyaht ${ }^{96}$. Harizmşah bayrağının siyah olması hükümdarın, kendilerini Sultan Sancar'ın ölümünden sonra Büyük Selçuklu İmparatorluğu'nun meşru varisi görmelerinden ileri geliyordu ${ }^{97}$. Her ne kadar Moğolların Buhara muhasarasını gösteren bir İran minyatüründe Harizmşahların bayrağı sarı renkte gösterilmiş ise de sonraki bir devre ait olan resmin hakikate uygunluğu iddia olunamaz ${ }^{9}$. Bunun yanında diğer Türk devletlerinde olduğu gibi Harizmşahlarda da hükümdara, veliahda hanedan azasına tabi küçük devletlerin reislerine mahsus bayraklardan başka büyük emirlerin kabile reislerinin muhtelif askeri kıtaların da hususi bayrakları bulunurdu. $\mathrm{Bu}$ devlete mensup hacılar kafilesinin önünde de mensup oldukları devletin sancağını taşıyan bayrak çekilirdi ${ }^{99}$.

Eyyubilerde hükümdara mahsus sancağın rengi sarı idi. Selahaddin Eyyubi'nin vefatından sonra söylenen şu mersiye Eyyubi Devleti'nin

\footnotetext{
94 İbn Bibî, s. 664; Turan, Selçuklular Zamanında Türkiye, s. 569; Uzunçarş11ı, a.g.e., s. 30; Merçil, a.g.e., s. 234. Memlük sultanı Baypars tarafından Altın Ordu hanı Berke'ye gönderilen heyet, Han'ın kıyafetini anlatırken kırmızı çizmelerinden de bahsetmesi bu geleneğin Moğollarda da mevcut olduğunu gösterir. Bkz. Uzunçarşıll, a.g.e., s. 187, not 3.

${ }_{95}$ Köprülü, "Bayrak", $\dot{I} A$, II, s. 409.

96 Taneri, Celaluddin Harizmşah ve Zamanı, Kültür Bakanlığı Yayınları, Ankara, 1977, s. 9899; amlf, "Çetr", DIA, s. 294.

${ }^{97}$ Köprülü, "Bayrak", IAA, II, s. 409; Taneri, a.g.e., s. 100, 129.

${ }^{98}$ Köprülü, "Bayrak", $\dot{I} A$, II, s. 409.

${ }^{99}$ Köprülü, "Bayrak", $\dot{I} A$, II, s. 409.
} 
hâkimiyet sembolü olan rengi açıça belirtiyor: "Yürü, dünyaya malik ol/Ona malik olmağa en lâyı olan sensin/Her nereye teveccüh edersen,/Nusrat ve zafer senin sarı bayrağının yanındadır ${ }^{100}$. Bununla beraber, daha sonraki Eyyubi ordularında sarı ve kırmızı bayrakların mevcut olduğunu bildiğimiz gibi, Abbasi halifelerinin Eyyubi hükümdarlarına gönderdikleri siyah bayrakların da kullanıldığı bilinir. Yine sarı renkte çetr kullanan Eyyubilerin kendilerine şiar olarak sarıyı seçmelerinde, hiç şüphesiz Fatımi geleneğinin tesiri vardır. Mısır, hatta Suriye halkı imparatorluk rengi olarak sarı rengi tanıyorlardı. Fatımi sülalesinin meşru varisi olduklarını göstermek arzusu da Eyyubilerin bu tercihinde belirleyici olmuş olmalıdır ${ }^{101}$. Bununla birlikte, Sünni Abbasi hilafetinin Selahaddin'in Mısır'daki Şii yönetime son verir vermez ona siyah sancaklar göndermesi manidardır ${ }^{102}$.

Moğolların hâkimiyet sembolü olarak kullandıkları renkle ilgili olarak beyaz ve kırmızı renklerin ön plana çıktığını görüyoruz. Harizmşah müellifi Nesevî'nin naklettiği, Sultan Celaleddin'in düşmanları olan Moğolları aldatmak için onların bayrağına benzeyen beyaz bayraklarla İsfehan'dan Rey'e kadar gittiğine dair kaydı, Moğol sancaklarının rengi hakkında bize açıkça bilgi veriyor ${ }^{103}$. Moğollarda han ilan edilme, beyaz üzerine çıkarılma şeklinde mecazi olarak ifade ediliyordu. Cengiz Han, 1260 yılında Naimanları yenince "dokuz adet $a k$ tuğlu sancak çıkarttı ve bu sancağın bir siyah ay şekli vardı"104. Dahası tıpkı Türklerde olduğu gibi Moğollarda da beyazın uğur, kara rengin ise uğursuzluk alameti olarak kabul edildiği, o dönemi anlatan bir vekayinâmede verilen örneklerle çok sarih bir şekilde ortaya çıkar. Eserde, Cengiz Han ve çevresine ilişkin efsaneler aktarılırken beyaz rengin hassasiyetle kullanılması (beyaz doğan, beyaz hırka, beyaz at, beyaz inek, beyaz öküz, beyaz taş, vs.) beyazın uğur, müjde ve liyakat alameti olarak Moğol devlet ve toplum yaşantısındaki değerine önem atfediyor ${ }^{105}$.

${ }^{100}$ Yaltkaya, "a.g.m.”, s. 44-45.

${ }^{101}$ Köprülü, "Bayrak", İA, II, s. 410.

102 İbnu'l Esir, el-Kamil fi't Tarih, (çev. A. Özaydın), C. XI, Bahar Yayınları, İstanbul, 1987, s. 298.

103 Nesevî'den aktaran Aydın Taneri, a.g.e., s. 133. Celaleddin'in babası Muhammed de düşmanı aldatmak için onların elbiselerinde benzer elbiseler giyme adetinde idi. Bkz. Barthold, Türkistan, s. 380.

${ }^{104}$ Barthold, Türkistan, s. 408 ve not 23, s. 545.

105 Anonim, Moğolların Gizli Tarihi, (çev. A. Temir), TTK Yay., Ankara, 1995, s. 19, 30, 56.

Cengiz Han, birini Bek'i (Şaman falcı) olarak atarken şöyle buyurmuştu: Beyaz bir hırka 
1246' daki Moğol Kurultayı'nda kurulan 2 bin çadırın da beyaz renkte olduğuna dair Cüveynî (öl.1283)'nin haberi, Moğolların beyaz rengi önemsediğini gösteren bir başka örnektir ${ }^{106}$. Aynı tarihlerde 1245-1247 yılları arasında Güyük Han'1 ziyaret etmiş olan John Pian de Carpini (öl.1252), beyaz renkli ve görkemli Moğol hanedan çadırlarından övgüyle söz eder ${ }^{107}$. Marco Polo (öl. 1324) da Moğolların festival kutlamalarını anlatırken onların her yılın Şubat ayında Beyaz Festival adını verdikleri bir şölen düzenlediklerini, bu şölende kağandan halka kadar kadın-erkek herkesin beyazlar giydiğini yazmakla beyaz rengin Moğollar arasındaki değerine dair ikna edici bir kayıt düşüyor ${ }^{108}$. Buna karşılık kara renk Moğol toplulukları için tamamıyla farklı anlamlar içeriyordu. Mesela Moğolların düşmanları olan Naimanlar, yakınlarında olan Moğollara saldırma konusunu müzakere ederken içlerinden biri (Curbesu) onları aşağılamak için şöyle demişti: "Onları (Moğolları) ne yapalım? Moğol halkı pis kokar ve kara elbiseler giyer. Şimdi bizden uzaktırlar ve orada kalsınlar"109. Ayrıca Moğolların, araba veya örtülerinin rengini de kabileleri işaret eden bir sembol olarak kullandıklarına dair güçlü ihtimaller vardır ${ }^{110}$.

Moğollarda devlet kayıtlarının tutulduğu defterler, yazıldığ mürekkebin rengine göre isimlendiriliyordu. Altan (Sarı) Defter, Koko-Köke (Mavi Defter) gibi. Moğolların mavi (Köke=Gök) renge atfettikleri değer, yasa ve mahkeme gibi önemli kayıtların tutulduğu defterlerin mavi mürekkeple tutulmasından anlaşılıyor. Cengiz Han bir keresinde Şigihutuhu'yu yüksek mahkeme reisliğine tayin ederek ona şöyle dedi:

giysin/Beyaz bir ata binsin/En yüksek yere otursun/Kendisine hürmet edilsin! Bkz. Aynı Eser, s. 146. Ayrıca bkz. Barthold, Türkistan, s. 416; Kafesoğlu a.g.e., s. 229-230, not 144.

106 Barthold, Türkistan, s. 512. J. A. Boyle'nin İngilizce çevirisinde sadece iki bin çadır kurulduğu yazılıdır. Krş. Ala-ad-Din 'Ata-Malik Juvaini, The History Of The WorldConqueror, (İng. Terc. J. A. Boyle), C. I, Harvard Universty Press, 1958, s. 250; Türkçe trc. s. 267.

107 John of Pian de Carpini, "The Journey (1245-1247)", Contemporaries of Marco Polo, (ed. M. Komroff), Liveright Publising Corp., New York, 1937, s. 40. Ayrıca bkz. Ögel, a.g.e. II, s. 76; Ligeti, a.g.e., I, s. 132, 147.

108 Marco Polo, The Travels of Marco Polo, (İng. Çev. H. Murray), Oliver and Boyd, Tweeddale Court, Edingburg, 1845, s. 127. Bu festivalde Kağan'a sunulan değerli eşyalar arasında elbise ve atların dahi beyaz olduğu kaydı dikkat çekicidir. Bkz. Aynı Eser, s. 127128.

${ }^{109}$ Moğolların Gizli Tarihi, s. 112.

110 Moğolların Gizli Tarihi, s. Açıklama kısmı not 6 ve 55. Cengiz Han'ın annesi onun, kardeşi Hasar ile vuruşmaya gittiğini duyduğunda aynı gece kara arabaya ak deveyi koşarak peşlerinden hareket etti. Aynı Eser, s. 163. Ayrıca bkz. Ligeti, a.g.e., I, s. 147. 
"Halkın taksimi meselesi ve mahkeme kararları Koko Debter (Mavi defter)'e kaydedilsin. Şigihutuhu'nun benimle istişare sonunda ak kâğıt üzerine mavi yazı ile yazarak defter halinde tespit ettiği esaslar nesilden nesle intikal etsin ve onu kimse değiştirmesin, değiştirmeye kalkanlar cezalandırılsın"111.

Moğollarda farklı alametler için farklı renklerin sembol olarak kullanıldığını da görüyoruz. Mesela, Hülagü’nün kendisine mahsus işler için siyah bir bayrak kullanması, siyah rengin Moğollar tarafından da egemenlik sembolü olarak kullanıldığını gösteriyor ${ }^{122}$. Bunun yanında kırmızı renk saltanat sembolü olarak Moğollarda da kullanılıyordu. Cengiz Han, yeşil ve kırmızı çetr kullanmıştır ${ }^{113}$. Altın ordu hanı Berke de Selçuklu hükümdarları gibi kırmızı çizme giymekteydi. Ayrıca Moğolların yazışmalarda kullanılan mühür renklerinin, belgelerin önem derecesini ve hiyerarşisini tayin eden bir sembol olarak kullanıldığını da görüyoruz. Mesela yarlığ adı verilen fermanlara kırmızı renkli mühürler vurulurdu ve bunlara Al Tamga (kırmızı mühür) adı verilirdi ${ }^{114}$. Kök Tamga (mavi mühür) adı verilen bir mühür de kullanımdaydı ki, ancak en mühim meselelerde ve genellikle Han ailesine mensup yazışmalarda kullanılıyordu ${ }^{115}$. Bunun yanında altın (sarl) tamga ve siyah tamga da Moğollarca kullanılıyordu ${ }^{116}$.

Moğolların kolu olan Altınordu Devleti'nin bayrağı, beyaz zemin üzerinde bir kırmızı hilal ile yine bir kırmızı damga taşımaktadır. İlhanlılar da sair Moğol devletleri gibi Cengiz geleneğini takip ederek hükümdara mahsus sancaklarda beyaz rengi kullanmaktaydılar. Hükümdardan başka hanedana mensup prensler, askeri kumandanlar da ayrı ayrı şahsi bayrak ve renkler kullanıyorlardı. Mesela, bir Moğol emiri olan emir Ahmed Halac'ın bayrağı kırmızı idi. Hükümdarın şahsi sancağı ile diğer saltanat sancaklarından başka orduda sarı, kırmızı ve sair renklerde türlü bayraklar kullanılıyordu. Bazı Moğol emirleri Ebu Said Bahadır Han'a isyan ettikleri zaman hükümdar kendilerini affettiği takdirde sulh alameti olmak üzere

\footnotetext{
${ }^{111}$ Moğolların Gizli Tarihi, s. XI-XII, 136.

112 Yaltkaya, "a.g.m.", s. 44.

113 Taneri, "Çetr", DİA, s. 294. Gordlevski'ye göre, Moğollar kırmızı renkli sancak kullaniyorlardı. (bkz. Gordlevski, a.g.e., s. 65.)

114 Şemseddin Günaltay, İslam Tarihinin Kaynaklarl, Tarih ve Müverrihler, Endülüs Yayınları, İstanbul, 1991, s. 234, not 5. Moğollar, 1221 civarında Nişapur'u kuşattıklarında kent halkına Uygur yazısı ile yazılıp kırmızı mum ile mühürlenmiş bir ferman göndererek onları kendilerine itaate davet ettiler. Bkz. Barthold, Türkistan, s. 449.

${ }^{115}$ Barthold, Türkistan, s. 411 ve not 45.

116 Uzunçarşıll, a.g.e., s. 197-199.
} 
ordusunda beyaz bayraklar çektirmesini istemişlerdi ${ }^{117}$. Cengizlere mensup büyük imparatorlar tarafından teşkil edilen birtakım devletlerde hükümdar bayraklarında beyaz renk kullanılmaktaydı. Celayirlilerin beyaz bayrak kullandıkları kolaylıkla tahmin edilebileceği gibi, çağdaş kaynakların ifadelerine göre Özbek hanı Ubeyd Han'ın da beyaz bayrağı mevcuttu ${ }^{118}$. Kendisini Cengiz imparatorluğunun meşru varisi sayan Timur'un hükümdara mahsus beyaz sancağından (tuğ) başka ordusunda türlü renklerde ve bilhassa sarı, kırmızı, mor ve beyaz bayraklar kullandığı tarihi kaynaklardan anlaş1lyyor. Timur'un torunu Mehmet Mirza, Anadolu seferinde maiyetindeki kıtaların her birini ayrı renklerde elbise ve bayraklar ile donatmışt1 ${ }^{119}$.

Abbasileri, dolayısıyla da Sünni İslam'ı şiar edinmiş olan diğer bütün Türk devletleri gibi Misır'da kurulan Memlükler de siyah rengin maneviyatını tanımışlardı. Güçlü Memlük hükümdarı Baypars, 1258 yılında Moğollar tarafından Abbasi Devleti'nin yıkılması üzerine 1260 tarihinde Abbasi hilafetinin varisi olan zata biat ederek sırtında bu halifenin şiarı olan siyah cübbe ve başında menekşe renginde sarık, boynunda altından boyunluk ve belinde bir Arap kılıcı olduğu halde halifenin huzuruna gelmişti ${ }^{120}$. Bununla birlikte, Memlüklerde manevi ya da siyasi sembol olarak kabul edilen renkler birbirinden farklı idi. Memlük Devleti de aynı coğrafyada kurulmuş bir devlet olarak Eyyubiler ve Fatımiler gibi sarı rengi sembol seçmişti ki isaba adı verilen sancakları ve hükümdar çetri hep bu renkte olurdu. Memlük sultanları, Altın-ordu hanlarına sair birçok hediyelerle birlikte Abbasi halifesine mahsus olan siyah renk ve kendi sarı bayraklarından da yollarlardı. Hatta bir defa Sırp kralının talebiyle ona da sırma ile işlenmiş sarı saltanat sancağı yollanmıştı. Memlüklerde ayrıca sarı ve kırmızı iki büyük sancakla üzerine feth ve zafer ayetleri yazılmış 400'den fazla daha küçük bayrak da mevcuttu' ${ }^{121}$. 14. Asırda yaşamış olan bir İspanyol Fransisken seyyahı, Şam ve İskenderiye'de sarı renkli bayrakları ön plana çıkarırken Kahire'de Melik Nasır b. Kalavun (öl.1341) döneminde

\footnotetext{
${ }^{117}$ Günümüz savaş hukukunda da beyaz bayrak çekilmesi, teslimiyet ve barış talebini ifade etmektedir.

${ }^{118}$ Köprülü, "Bayrak”, $\dot{I A}$, II, s. 413.

119 Köprülü, "Bayrak", IA, II, s. 413-414.

${ }^{120}$ Anonim, Baypars Tarihi, (çev. Ş. Yaltkaya), TTK Yayınevi, Ankara, 2000, s. XV.

${ }^{121}$ Köprülü, "Bayrak", IA, II, s. 410-411.
} 
Memlük bayrağını beyaz zemin üzerine mavi bir hilal şeklinde tanımlamıştır ${ }^{122}$.

Topkapı müzesinde, Memlük bayrağı olarak üstünde bir kırmızı hilal bulunan altın sarısı renginde bir sancağa yine Memlüklere ait İskenderiye şehri üzerinde altın sarısı bir zemin üzerinde bir kırmızı daireyi ihtiva eden diğer bir bayrağa tesadüf edilmektedir ${ }^{123}$. Ayrıca Memlük ordu düzeninde, renklere göre sınıflandırma sisteminin var olduğunu görüyoruz. Buna göre, Mısır'da yüzlerbaşı beylerinin her birinin kendine özgü bir rengi vardı ve bunların hepsinin kendilerine ait olan binalarının kapıları üzerinde bu renk bulunurdu ${ }^{124}$.

\section{BEYLIKKLER, AKKOYUNLU, KARAKOYUNLU VE SAFEVİ DEVLETLERINDE RENK GELENEĞİ}

Moğol istilasından sonra, Anadolu'da ortaya çıkan beylikler ve bunların kullandıkları sembol renkler hakkında fazla bilgi yoktur. Bununla birlikte, Anadolu beyliklerinin hâkimiyet alameti olarak tercih ettikleri renklerin genel olarak Memlük, Anadolu Selçuklu ve İlhanlı devletlerinde tesadüf edilenlerden pek farklı olmadığı tahmin edilebilir. Enverî'nin Düsturnâme'sine bakılacak olursa, Aydınoğullarından Gazi Umur Bey'in gemisinde yeşil sancak bulunmaktaydı ve bu renk belki de kuvvetli bir cihad ruhu ile donanmış bulunan Anadolu gazilerinin tercih ettikleri bir renkti ${ }^{125}$. Bunun yanında dönemin kaynaklarında geçen bayrak tasvirleri, kullanılan renklerle ilgili bir fikir verebilir. Buna göre Candaroğullarına ait olan Sinop üzerindeki bayrak, kırmızı zemin üzerine sola doğru açılmış bir altın sarısı ay taşımaktaydı. Teke oğullarına ait bayrak beyaz zemin üzerinde kırmızı altın köşeli yıldız taşıyan ve ucunda iki tane zikzaklı yeşil çizgi bulunan bir sancaktır ${ }^{126}$. Son olarak Anadolu beyliklerinin, Moğol tahakkümü altında bulunan Selçukluların beyaz renkli Moğol sancaklarını da kabul ettikleri kuvvetle muhtemeldir ki, Selçuklu sultanı Alâeddin o sırada ecnebi sınırında

\footnotetext{
122 A Spanish Franciscan, Book of The Knowledge, (Published 1st time: Marcos J. De La Espada, in 1877), (İng. Sir Clements Markham), Hakluyt Society, London, 1912, s. 22-23.

${ }^{123}$ Köprülü, "Bayrak", IA, II, s. 410-411.

${ }^{124}$ Baypars Tarihi, s. 101, not 1. (Subhu'l Aşa, C. IV s. 61-62'den naklen) Günümüzde de askeri sınıfların hepsinin ayrı renklerde bayrak ve flamaları bulunmakta, her tabur ayrı bir renk ile sembolize edilmektedir.

${ }^{125}$ Enverî̀ den aktaran Köprülü, "Bayrak”, IA, II, s. 411; Uzunçarşıl1, a.g.e., s. 146.

${ }^{126}$ Köprülü, "Bayrak”, IA, II, s. 411.
} 
yararlılıklar gösteren Osman Bey'e hâkimiyet alameti olarak beyaz bir sancak göndermişti ${ }^{127}$.

Tarihi kaynaklar, Akkoyunlara ait sancağın beyaz renkli olduğunu doğruladıkları gibi, bunların Akkoyunlu aşiretler birliğinin bir alameti olarak üzerinde ak koyun resmi bulunan bayraklar da kullandıklarını söylerler. Büyük emirlerin maiyetindeki askeri kıtaların ayrı ayrı bayrakları olduğunu bildiğimiz gibi, hükümdarın ismi ile fetih ve zafer ayetlerini yahut bayındır damgasını taşıyan türlü renklerde bayraklar da vardı. Karakoyunlulara gelince: Hükümdar bayrağının, beyaz zemin üzerine nakşedilmiş bir kara koyun resmini ve belki de hükümdarın ismini ve damgasını taşıdığı tahmin edilen bu devlette diğer Türk devletleri gibi muhtelif emirlerin ve kabile reislerinin üzerlerinde kendi damgalarını taşıyan türlü renklerde ve şekillerde bayraklar kullandıkları tabiidir ${ }^{128}$. Özetle, bu iki Türkmen devletinin ezeli rekabetinde de siyah ve beyaz renklerin birbirine zıtlığı kullanılmış, birinin ak dediğine öteki kara demiştir.

Safevi Devleti zamanındaki bayraklar hakkında malumat pek azdır. Yukarıda genel olarak Şiilerin yeşil renge atfettikleri önemden bahsettik. Şah İsmail zamanına ait eserlerde onun yeşil bayraklarından bahsolunur ki $\mathrm{Hz}$. Peygamber sülalesinden olduğunu iddia ve İsna Aşeriye Şiiliğini resmi mezhep kabul eden bu Türk hükümdarının bu rengi seçmesi gayet tabiidir. Çünkü o asırlarda yeşil renk bütün Yakındoğu'da Hz. Peygamber ailesinin şiarı addediliyor ve bütün İslam dünyasındaki seyyidler yeşil sarık ile diğer halktan ayrilıyorlardı. 18. asırda Avşarlar sülalesinden Nadir Şahlar zamanında Nadir Şah'ın yeğeni Ali Şah beyaz renkli bayraklar kullanmıştır. Avşar sülalesinin resmi bayrağı olduğu için Nadir Şah zamanında da bu renkte bayrak kullanıldığı söylenebilir. Safevilerin dini siyasetine tamamıla muhalif bir siyaset takip eden Nadir'in onların yeşil rengini bu suretle beyaza çevirmiş olması belki de İlhanlılar devrinden Safevilere kadar İran'da bu rengin imparatorluk rengi olarak kullanılmasından dolayıdır ${ }^{129}$.

\footnotetext{
${ }^{127}$ Pakalın, “Alem” OTDTS, I, s. 48.

${ }^{28}$ Köprülü, "Bayrak", IA, II, s. 414; M. Halil Yinanç, "Akkoyunlular", IA, C. I, MEB Yayınevi, Eskişehir, 1997, s. 266; Yaltkaya, “a.g.m.”, s. 45.

${ }^{129}$ Köprülü, "Bayrak”, IA, II, s. 415.
} 


\section{OSMANLI DEVLETINDE RENK GELENEĞİ}

Konya'daki Selçuklu sultanı Alâeddin'in, Osman Gazi'ye gönderdiği hâkimiyet alametleri arasındaki bayrağın, Moğolların şiarı olan beyaz renkte olduğunu yukarıda belirtmiştik. Bununla birlikte, 15. asırda Osmanlıların kırmızı bayraklar kullandıkları Âşık Paşazade'nin Alaşehir'de dokunan bir çeşit kırmızı kumaştan bayrak ve hilat yapıldığ 1 hakkındaki kaydından anlaşılıyor. Ayrıca kırmızı rengin daha Osman ve Orhan Bey zamanlarında kullanıldığını bu dönemde savaşlarda kırmızı savaş bayrağı çekilmesinden anlıyoruz. Fatih'in muasırı Tursun Bey'in ifadelerinden anlaşıldığına göre, bu devirde Osmanlı donanmasında kırmızı, yeniçeri kıtalarında ise beyaz bayraklar kullanılmıştı ${ }^{130}$. Yine Fatih devrinde padişah rükübuna mahsus geminin arkasına asılmak üzere yeşil sancak ihdas edildiği de düşünülmektedir. İstanbul'un fethi sırasında boğazdan kızaklarla Haliç'e nakledilen gemiler ve şimdiki filolar gibi renk renk bayraklarla donatılmışt1 ${ }^{131}$.

Doğrudan doğruya padişaha mahsus bayrak, Fatih devrinde ak sancak idi ki; II. Beyazid, I. Selim ve Kanuni devirlerinde de bunun değişmediğini çeşitli kaynaklardan öğreniyoruz. İlhanlılar devrinden beri Anadolu'da imparatorluk rengi olarak kullanılan $a k$ sancağın Fatih'ten evvelki Osmanlı padişahları tarafından da hiç olmazsa Yıldırım Beyazid'den beri kullanıldığı tahmin edilebilir. Yeniçerilerin ak bayrağı ile süvari ocaklarının alaca kızıl ve sarı bayrakları Kanuni Süleyman'ın ilk zamanlarında devam ediyordu. Yalnız 16. asırda imparatorluğun azametli inkişafı sonucu Kanuni, o zamana kadar dört renkte olan bu bayrakları altıya çıkarmıştır. Kanuni devrinde ilave edilen bu bayrakların yeşil ve siyah renkte olduğu söylenebilir. Macaristan seferine çıkan orduya kumandan tayin edilen Sadrazam İbrahim Paşa'ya beyaz, yeşil ve sarı renklerde üç sancakla, iki kırmızı ve iki tane de alaca bayrak verildiği hakkındaki kayıtlar bunların hükümdarın hassa kuvvetine mahsus sancaklar olduğunu anlatıyor ${ }^{132}$.

Hükümdarların ak sancaktan başka bilhassa kızıl sancak da kullandığı, Mısır'ı fethettiği zaman I. Selim'in otağının önünde ak ve kızıl iki sancak dikilmesinden anlaşılıyor. Osmanlılarda yeşil renkli sancağın eskiden beri kullanıldığı söylenebilir. Aydınoğlu Umur Bey'in gemisine çekilen sancağın yeşil olması, dini mahiyette olan bu rengin cihad ve gaza mefhumu ifade

${ }^{130}$ Aktaran Köprülü, "Bayrak”, IA, II, s. 416; Pakalın, “Alem” OTDTS, I, s. 48.

${ }^{131}$ Pakalın, "Alem" OTDTS, I, s. 48.

132 Köprülü, "Bayrak”, IA, II, s. 417. 
ettiğini gösterir. Yeşil renkli sancakların, gazilere mahsus olduğunu ve bunun daha ziyade denizciler tarafından kullanıldığını gösteren çeşitli deliller vardır. İstanbul kuşatmasında Fatih'in gemisinde yeşil renkli sancak bulunması, 16. asrın büyük denizcisi Barbaros'un bayrağının üzerinde Zülfikar şekli ile zafer ve fetih ayetleri bulunan yeşil kumaştan olması, İnebahtı muharebesinde Cezayir beylerbeyi Uluç Ali Paşa'nın gemisinde üzerinde beyaz bir pençe ile fetih ve zafer ayetleri nakşedilmiş yeşil sancak bulunması, Piyale Paşa donanmasının İstanbul'dan hareketini tasvir eden bir Frenk seyyahının ifadesine göre kumandan bayrağının yeşil olması, Cezayir gemilerinin 17. asırda yeşil sancak taşımaları, Rumeli serhadlerinde yaşayan gazilerin o devrin ananesine göre çeteye (yani akına, çapula) çıkarken yeşil bayrak kullanmaları gibi ${ }^{133}$.

Yeniçeri Ocağı'nın sancağı, yarısı kırmızı, yarısı yeşil renkte olup kenarları sarı sırma harçlı ve ortasında yine sarı sırma bir zülfikarı içermekteydi. Topçu Ocağı sancağında kırmızı, beyaz ve sarı renkler kullanılmıştı. Silahtar bölüğünün bayrağı sarı renkliydi, ortasında beyaz sırma ile işlenmiş iki hilal vardı. Sipah bölügünün bayrağı da aynı şekilde olup rengi kırmızıydı. Dört bölük bayrağı yeşil ve beyaz (kırmızı ve beyaz) yollu bayraktı. Kapıkulu süvarisinin mızraklarında yarısı kırmızı, yarısı yeşil ve üç tarafı yırtmaçlı küçük bir bayrak bulunurdu. Eyalet süvarisinden delil askerinin bayrağının yarısı kırmızı yarısı yeşil olduğu gibi gönüllü süvarisinin bayrağı da yarısı kırmızı yarısı sarıydı. Topraklı süvarisi adı verilen Tımarlı sipahilerin bayrağının yarısı kırmızı yarısı yeşil renkteydi ${ }^{134}$.

Topraklı süvarisinin bayrakları, yukarısı yeşil ve aşağısı kırmızı renkte olmak üzere iki renkliydi. 15. asırda bilhassa kırmızı bayraklar kullanıldığı halde (Fatih ve II. Beyazit devirlerinde) 16. asırda kumandana mahsus bayrakların yeşil olduğunu memleketin muhtelif mıntıkalarına mensup derya beylerinin de beyaz, kırmızı, sarı, sarı-kırmızı ufki çizgili (alaca) bayraklar kullandıkları malumdur. $\mathrm{Bu}$ sirada ticaret gemilerinin beyaz bayraklar taşıdıkları bazı edebi kaynaklardan anlaşılıyor. I. Mahmud devrinden sonra donanmada en ziyade yeşil sancaklar kullanılmaya başlandı. Kalyonların kıç sancakları yeşil olduğu gibi amirallere mahsus forslar da yeşil zemin üzerinde zülfikar ve hilal şekillerini ihtiva ederdi. 1793'te kaptan Küçük

${ }^{133}$ Köprülü, "Bayrak”, IA, II, s. 417-418; Pakalın, “Alem” OTDTS, I, s. 48.

${ }^{134}$ Pakalın, "Alem" OTDTS, I, s. 48-49. 
Hüseyin Paşa'nın teşebbüsü ile gemi bayraklarında daha ziyade kırmızı rengin kullanılmaya başladığını görüyoruz ${ }^{135}$.

III. Selim devrinde Nizam-ı Cedit kıtaları için ihdas edilen ortasına sarı sırma ile bir hilal yahut ortadaki hilalden başka dört köșesine hilal işlenmiş kırmızı veya fes rengi bayraklardan bazıları Topkapı müzesinde saklanmaktadır. Ay yıldızın III. Selim zamanında bayrağa konulduğu kuvvetli bir ihtimal olarak kabul olunabilir. Asakir-i Mansure-yi Muhammediye'ye ait olarak üzerinde kelime-i şehadet veya fetih ayetleri bulunan siyah bayraklar yapılmıştı. Bunlarda siyah rengin tercihi $\mathrm{Hz}$. Peygamber'in $U k a b$ adlı meşhur siyah bayrağının rengini taklit maksadı ile olmuştur. 19. yüzyılın ilk yarısında üzerinde hilal ve yıldız işareti bulunan kırmızı (al) sancağın o zamanki batı devletlerinin resmi bayrakları gibi Osmanlı İmparatorluğu'nun resmi ve umumi timsali yani millî bayrak olarak

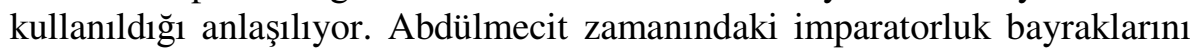
gösteren bir albümde bayraklar umumiyetle kırmızı renktedir ve ortalarındaki muhtelif alametler de beyazdır. Bu devirde yeşil rengin, hacılara mahsus gemilerin bayraklarına tahsis olunduğunu görüyoruz. Osmanlı İmparatorluğu'nda daha 14. asırdan başlayarak tarikatlere mahsus (daha ziyade siyah ve yeşil renklerde) üzerlerinde ayetler ve pirlerin isimleri bulunan bayraklar kullanıldığı gibi esnaf teşekküllerinin de ayrı ayrı bayrakları olduğu bilinir ${ }^{136}$. Celali eşkıyasının türlü renklerde üzerinde şekiller ile beraber zorba başıların isimleri de yazılı yüzlerce bayrak kullandıklarını Naima kaydeder ${ }^{137}$. Ayrıca Osmanlı İmparatorluğu'nda ilmiye sınıfının da her rütbesine mahsus ayrı ayrı renklerde binişi vard ${ }^{138}$.

\section{TÜRK TOPLUM YAŞAMI İÇERISSINDE RENKLER}

Yukarıda anlatılanlardan açıkça anlaşılıyor ki; bayrak, sancak, tuğ ve alem gibi bir devletin siyasi sembolü haline gelmiş olan unsurlar dönemin kaynaklarında daha fazla yer aldığından İslam/Türk devlet geleneğinde renkler konusunda daha ziyade bu unsurlar vasitasıyla bilgi edinmekteyiz. Bununla birlikte, renklerin özellikle Türk sosyal yaşantısı içerisinde siyasi anlamı dışında ifade ettiği anlamları üzerinde de durmak gerekir. Türklerin İslamiyet'i kabulden önceki inanışlarına temel oluşturan ve gökyüzünün rengi olması sebebiyle mavi rengin Türkler arasında önem arz ettiğini

\footnotetext{
${ }^{135}$ Köprülü, "Bayrak”, $\dot{I} A$, II, s. 418.

${ }^{136}$ Köprülü, "Bayrak", IA, II, s. 419; Pakalın, “Alem” OTDTS, I, s. 48.

${ }^{137}$ Naima' dan aktaran Köprülü, "Bayrak”, IA, II, s. 416.

${ }^{138}$ Baypars Tarihi, s. 101, not 1.
} 
söylemiştik. Esasen Arapça olan mavi kelimesinin eski Türkçedeki karşıllı̆̆ Gök = Kök kelimesidir ${ }^{139}$. Türk mavisi ya da Turkuaz olarak bilinen bu rengi, Türklerin daha çok mimari anıtlarda kullandıkları bilinmektedir. El yazmaları desenlerini de koyu mavi bir zemin Türk mavisi süslemekteydi ${ }^{140}$. Türkler bu kelimeyi çeşitli adlandırmalar için de kullanmıştır. Gök-Türk, Gök-Orda, Gök-Böri, Gök-Han, Gök-ce, Gök-su gibi.

Siyah rengin, Türk toplumunda millî renk addedildiğini yukarıda türlü vesilelerle ifade ettik. Farsça olan bu kelimenin Türkçedeki karşıllğı olan kara birçok toplumda olduğu gibi Türkler arasında da matem ve hüzün alameti olarak kullanıliyordu ${ }^{141}$. Orhun Kitabeleri'nde olsun, Dede Korkut'ta olsun kara renk bir yas, bir ızdırap ve acının karşılığıdır ${ }^{142}$. Bizans müellifi Anna Komnena'nın bir kaydına göre, Bizans'ın Anadolu'da yaptığı bir katliamdan sonra birçok soydaşlarının öldürülmesi, beşikte yeni doğmuş çocukların bile kaynar kazanlara atılması sonucu, bu katliamdan kurtulabilen Türkler matem alameti olarak karalar giyinerek Türk beldelerine dağıldılar ve Türkleri intikama çağırdılar ${ }^{143}$. Aynı şekilde, sultan Melikşah'ın 11 yaşındaki oğlu Melik Ahmed'in ölümü üzerine, Türkmenler yas alameti olarak karalar giymişler, binalarının kapısını siyaha boyamışlard ${ }^{144}$. Cüveynî, Harizmşah sultanı Alâeddin Muhammed'in bir rüyasını aktarırken onun rüyasında karalar giymiş yas tutan kadınlar gördügünü ifade ederek bu noktayı sarih bir şekilde ortaya koyar ${ }^{145}$. İbn Battuta, Candaroğlu İbrahim Beg adlı kişinin annesinin cenazesinde, Sinop'ta bulunan kadı, fakih ve hatibin başlarına sarık yerine siyah örtüler sardıklarını anlatır ${ }^{146}$.

\footnotetext{
139 Şemseddin Samî, Kamus-ı Türkî, Çağrı Yayınları, İstanbul, 1996, s. 1264.

140 Gordlevski, a.g.e., s. 242.

${ }^{141}$ Turan, Selçuklular ve Türk Islam Medeniyeti, s. 238.

${ }^{142}$ Mustafa Kafalı, “Türk Kültüründe Renkler” Yörtürk Dergisi, (Mart-Nisan 2002), Say1: 42, s. 41. Kara sıfatı, eski Türkçede halk anlamına gelen bodun kelimesiyle kullanılarak sıradan halk (kara-bodun) tabirini de karşılamıştır. Beyler için ise ak (ak-beg) kelimesi tercih edilmektedir. Bkz. Kafesoğlu a.g.e., s. 129-130. dipnot 140, 145.

143 Anna Comnena, (Komnene), The Alexiad, (Edited and translated by E. A. Dawes), London, 1928, s. 361; Turan, Selçuklular ve Türk İslam Medeniyeti, s. 292; amlf., Selçuklular Zamanında Türkiye, s. 150; amlf., Türk Cihan Hâkimiyeti, I, s. 207.

${ }^{144}$ Turan, Selçuklular ve Türk İslam Medeniyeti, s. 209.

${ }^{145}$ Cüveynî, I, s. 205. Ayrıca bkz. Ahmet Eflakî, Ariflerin Menkıbeleri, C. I, (çev. T. Yazıcı), MEB Yayınevi, İstanbul, 2001, s. 599.

${ }^{146}$ Ebu Abdullah Muhammed İbn Battuta Tancî, İbn Battuta Seyahatnâmesi, (Çev. A. S. Kazancıgil), C. I. Yapı Kredi Yayınları, İstanbul, 2010, s. 444; Uzunçarşıll, a.g.e., s. 137, not 3; Gordlevski, a.g.e., s. 307. Gordlevski, Sinop Türklerinin yas alameti olarak siyah rengi kullanmalarını Bizans'a yakın olmalarına ve onlardan etkilenmelerine bağlıyor. (Bkz. Aynı
} 
İslam/Türk toplumlarında beyaz rengin de matem göstergesi olarak kullanıldığ görülür. İslam öncesi Türk toplumlarında yuğ adı verilen cenaze merasimlerinde yas alameti olarak beyaz elbise giyilmesi geleneği mevcut olduğu gibi, Endülüs'te de beyaz renk hüzün ve matem alameti olarak telakki edilmiştir ${ }^{147}$. Ravendî̀nin eserinde, sultan Mesud'un ölümü (1152) vesilesiyle şair Seyyid Eşref'in ağzından nakledilen mersiyede geçen Ey Çetr, siyah elbise şimdi beyaz oldu şeklindeki ifadeyle hükümdarlık alâmeti olarak giyilen siyah elbisenin matem sebebiyle beyaza dönüştüğü ima edilir $^{148}$. Dahası, I. Alâeddin Keykubad'ın, kardeşi I. İzzeddin Keykavus'un ölümünden (1220) sonra; II. Giyaseddin Keyhüsrev'in de babası I. Alâeddin'in ölümü (1237) vesilesiyle beyaz atlas giyerek matem ayini yaptıklarına dair İbn Bibî'nin kaydı, Anadolu Selçukluların asırlar sonra dahi eski Türk geleneğini sürdürdüklerini göstermesi bakımından dikkate şayandır ${ }^{149}$.

Eski Türk inanışlarına dayanarak Türk toplumu arasında Gök (mavi) ve Kara renklerin hususi ve birbirine zıt anlamlar taşıdığını düşünülebilir. Türklerin inanışına esas oluşturduğundan "Gök" (gökyüzü, sema) kavramı, Türklerde kutsal addedilerek uğur telakki edilmiş ve kutsal addedilen isimler önünde kullanılmıştır (Gök-tanrı, Gök-Türk, Gök-Kurt gibi). Bunun zıddı olarak günümüz Türkçesinde kullandığımız yeryüzü anlamına da gelen "Kara" kelimesi de uğursuz sayılmış, matem alameti olarak kabul görmüştür ${ }^{150}$. Bununla birlikte kara sıfatının Türkçede aşağı bir dereceyi

Yer) Esasen siyah renk, birçok toplumda matem anlamına geliyordu ki, Abbasilerin de bu noktadan hareketle siyah rengi seçtikleri yukarıda kaydedilmişti. Tuğrul Bey’in ölümünün hemen akabinde Selçuklu heyetini karşılayan bir Ermeni prensi de karalar giyerek Tuğrul Bey'in yasını tuttuğunu göstermek istemişti. (Bkz. Turan, Selçuklular ve Türk İslam Medeniyeti, s. 156). Moğollarda da hükümdarların vefatında matem tutulur ve karalar giyilirdi. Olcayto Hüdabende'nin vefatından sonra yas alameti olarak karalar giyilmişti. (Uzunçarşıll, a.g.e., s. 181 ve not 6).

${ }^{147}$ Ögel, a.g.e., II, s. 85; Yaltkaya, “a.g.m.”, s. 45. Yaltkaya bu noktada haklı olarak şu soruyu soruyor: İslâm fikhında kefenin beyaz olması müstehaptır. Acaba beyazın matem alâmeti olması ile bunun bir münasebeti olabilir mi? Aynı Yer, dipnot 5.

${ }^{148}$ Ravendî, I, s. 236; Merçil, a.g.e., s. 107.

149 Bkz. İbn Bibî, (M. Öztürk), s. 233, 450;Turan, Selçuklular Zamanında Türkiye, s. 328; Merçil, a.g.e., s. 190.

${ }^{150}$ Günümüz Türkçesinde kara rengin uğursuzluğu ile ilgili var olan deyimler de (karalar bağlamak, kara baht, kara haber, kara toprak, kara günlere kalmak vs.) bu konuya işaret eder. (Geniş bilgi için Bkz. Nesrin Bayraktar, "Kara ve Siyah Renk Adlarının Türkçedeki Kavram ve Anlam Boyutu Üzerine", TÖMER Dil Dergisi, Sayı 126, Ekim-Kasım-Aralık 2004, s. 5677.) 
değil, aksine güç ve kudreti temsil ettiğine ve güçlü hükümdarlara bu lakabın verildiğine dair yorumlar mevcuttur. Gazneli Mahmud'un kendisi için "Kara Han" tabirini kullanması yanında Türk tarihinde adı geçen Kara Osman, Kara Mehmed ve Kara Yusuf gibi isimler bu duruma örnek olarak gösterilirr ${ }^{151}$. Aynı şekilde büyük surlarından dolayı ele geçirilmesi zor olan Amid (Diyarbakır) şehrine de "Kara Amid" denmesi bununla izah edilebilir.

Türk tarihinin muhtelif devrelerinde renklerin yönleri ifade etmek için de kullanıldığı bilinmektedir. Dört yönün her birisi ayrı renk ile şekillenmiştir. Bunlardan kara=kuzey, kızıl=güney, gök=doğu, ak=batı olarak kullanılır. Mesela Türkler, Anadolu'nun kuzeyindeki denize KaraDeniz, batısındakine Ak-Deniz, güneyindekine Kızıl-Deniz adını vermiş, fakat doğuda bu isimle adlandırılacak deniz bulunmadığı için büyükçe bir gölün adını da Gökçe-Göl olarak tanımlamışlardır. Aynı şekilde, Avrupa'ya giren Hunlar, Kuzey Hunlarının devamı olmaları hasebiyle Macar kaynaklarında Kara-Hunlar olarak bilinirler. Osmanlı tarihinde Boğdan'ın kuzeyi ifade edilmek istendiği zaman Kara-Boğdan şeklinde söylenmiştir. Buna benzer şekilde dağ, tepe, ırmak, deniz, şehir gibi pek çok coğrafî̀ isimleri bu renkler esas olmak üzere Türk coğrafyasında görmek mümkündür ${ }^{152}$. Bu dört renkle birlikte kullanılan bir beşinci renk vardır ki, o da sarıdır. Sarı renk yön değil, bu dört rengin ortasında yer alan merkezi karşılamak için kullanılmıştır. Devlet yapısı bakımından değerlendirilecek olursa, sarı renk merkez hâkimiyetini ve kudreti ifade etmektedir ${ }^{153}$.

Türk devletlerinde renklerin bir iletişim vasıtası olarak kullanıldığına dair bilgiler de mevcuttur. Birçok toplum için kırmızı renk, bir aciliyet ve alarm durumu ifade etmekteydi. Yukarıda, Sasani Devleti'nin bir savaşta hücuma kalkacağı zaman kırmızı renkte bayraklar çektiklerini belirtmiştik. Aynı geleneğin Türk devletleri için de geçerli olduğunu söyleyecek örneklere sahibiz ${ }^{154}$. Mesela, Harizmşah sultanı Celaleddin, seferberlik kararı aldığı zaman ordusunun ileri gelenlerine yani han, melik, emir ve bazen da çavuşlara kırmızı oklar göndermek suretiyle onlara maiyetiyle birlikte kendisine katılmaları mesajını veriyordu. Kırmızı oku alan kumandan derhal

\footnotetext{
${ }^{151}$ Kafesoğlu a.g.e., s. 229-230 ve not 144.

${ }^{152}$ Kafalı, "a.g.m.” s. 39; Divitçioğlu, a.g.e., s. 114.

${ }^{153}$ Kafal1, "a.g.m." s. 39.

${ }^{154}$ Kırmızı renk, Türkçede genellikle kızıl kelimesiyle ifade edilmekte, adlandırmalar bu kelime ile (Kızıl-deniz, Kızıl-elma, Kızıl-toprak gibi) yapılmaktaydı. Şemseddin Samî, "Bu güzel kelime dururken bu rengin özel bir çeşidi olan kırmızı kelimesinin kullanılması üzüntü vericidir” der. Bkz. Şemseddin Samî, s. 1127.
} 
maiyetindeki askerlerle sultana katılıyordu ${ }^{155}$. Sultan Celaleddin, ağır bir mağlubiyet aldığı 1230'daki Yassıçemen Savaşı öncesinde bey ve kumandanlarına kırmızı oklar gönderip askeri toplamalarını istemişti ${ }^{156}$. Bunun dışında savaşta hücum esnasında kırmızı bayrak çekilmesi usulü Osmanlilarda da mevcuttu ${ }^{157}$.

Renk seçimi, eski Türklerde giyim konusunda da kendini göstermekteydi. Özellikle ortaçağda Türklerin sıkça kullandıkları külahlarda tercih ettikleri renkler, bireysel bir tercih olmaktan ziyade onların hangi zümreye, hangi tarikate ya da hangi esnaf teşkilatına mensup olduğu konusunda bilgi vermekteydi. Türkler, kendilerini diğer zümre ve gruplardan ayırmak için farklı renklerde külah ve serpuş kullanmaktaydılar. Mesela, Harizmliler siyah külah giymekteydiler ${ }^{158}$. Külahlar, bazen idari bir görevin sembolü olmaktaydı. Nizamü'l-Mülk, Samanî saray hizmetlilerini anlatırken Visak-başı (çadır kumandanı) adı verilen görevlinin işaret olarak gümüş işlemeli siyah bir külah giydiğini belirtir ${ }^{159}$.

Karamanlı Türkmenleri, Karamanoğlu Mehmet Bey zamanına kadar kırmızı külah giymekteydi. 13. yüzyılın ortalarına doğru Anadolu'yu gezmiş olan Simon de Saint Quentin, Türkmenlerin kırmızı külahları üretip ihraç ettiklerini kaydediyor ${ }^{160}$. Bu kırmızı külahların 1260 yılından itibaren beyaza dönüştüğü görülüyor. Konyalı yazar Eflakî’ye göre de onun zamanında (14. yüzyıl), çok moda olan beyaz külahların çıkışını Mehmed Bey'e atfetmek gerekir $^{161}$. Antalya ve Alaiye (Alanya) gibi sahil mıntıkaları ile batı ve güney sınırında Menderes üzerindeki kesif aşiretler üzerinde büyük bir nüfuzu olduğu anlaşılan Mehmet Bey'in bu Türkmenlere kırmızı külahlarını değiştirip ak-börk (ak külah) giydirdiği rivayet edilir ${ }^{162}$. İbn Bibî, çeşitli vesilelerle bu Türkmenlerin kırmızı külah yanında üstlerine örttükleri siyah renkli kilimleri de zikretmektedir ${ }^{163}$.

155 Taneri, a.g.e., s. 130, 151.

156 Turan, Selçuklular Zamanında Türkiye, s. 371.

${ }^{157}$ Köprülü, "Bayrak”, IA, II, s. 403; Pakalın, “Alem” OTDTS, I, s. 48.

158 Taneri, a.g.e., s. 130.

${ }^{159}$ Nizamülmülk, Siyasetnâme, (Haz. S. Yalsızuçanlar), Lacivert Yayınc1lık, İstanbul, 2007, s. 139-140; Barthold, Türkistan, s. 215.

${ }^{160}$ Aktaran Cahen, a.g.e., s. 299.

${ }^{161}$ Eflakî, C. I, s. 717, C. II, s. 455 ; Cahen, a.g.e., s. 334.

162 Turan, Selçuklular Zamanında Türkiye, s. 514, 560; Cahen, a.g.e., s. 299. Bununla birlikte İbn Bibî, Cimri hadisesini anlatırken o tarihte (1277) dahi Türkmenlerin kırmızı külahla dolaştıklarından bahseder. Krş. İbn Bibî, (M. Öztürk), s. 631-632.

163 İbn Bibî, s. 631, 664. 
Ortaçağ Anadolu'sunun önde gelen esnaf örgütlenmesi olarak Ahiler de genellikle beyaz rengi tercih etmekte ve başlarına beyaz kalpak giymekteydiler. Beyaz rengi bir tür simge olarak kabul eden bu esnaf örgütü kırmızı baş giysileri taşıyan Türklerden kendilerini böyle ayırıyorlard ${ }^{164}$. Âşık Paşazade, Osmanlıların da Orhan Gazi zamanında çevre beylerin kızıl börklerinden farklı olması amacıyla askerleri için ak börk giyilmesini kabul ettiğini, başta sultanın kendisi olmak üzere askerlerin bu tarih itibariyle ak börk giydiklerini yazar ${ }^{165}$.

İslam/Türk toplumlarında renklerin farklı din ve zümrelere mensup olanları birbirinden ayırt etmek için kullanıldığı da vâkidir. Mesela Süryani Mihail, Nureddin Zengi'nin Hıristiyanların Müslümanlardan ayırt edilebilmeleri amacıyla saç uzatmamalarını, Yahudilerin de omuzlarında kırmızı bir bez bulundurmalarına dair bir kanun çıkardığını kaydetmektedir ${ }^{166}$. Aynı şekilde Anadolu Selçuklularının son döneminde Yahudi ve Hıristiyanların Müslümanlardan ayrı olmaları için külah ve sarı sarı giyme mecburiyeti getirildiğini dönemin yazarı Aksarayî kaydeder ${ }^{167}$. 14. asır seyyahı İbn Battuta da Denizli' deki gözlemlerini aktarırken şehirde çok sayıda Rum'un yaşadığını ve Rum erkeklerinin beyaz veya kırmızı renkteki uzun külahlarıyla tanındıklarını yazar ${ }^{168}$.

İslam/Türk toplumlarında farklı dini zümreler, Hz. Peygamber soyundan gelen seyyidler ve tasavvuf esasina dayanan tarikatlar de ayırt edici renkler kullanmaktayd $1^{169}$. Bu bağlamda, daha çok siyah ve yeşil renklerin ön plana çıktığını görüyoruz. Önceleri halifeleri ve sultanları temsil eden bu renkler, zamanla sofi şeyhlerine kalmış, cami ve tekkelerde bulunarak büyük şahısların cenazeleri önünce ve diğer önemli günlerde açılır hale gelmişti ${ }^{170}$. Bununla birlikte tasavvufi mezhepler arasında farklı renklerin tercih edildiği de vâkidir. Türkiye Selçukluları dönemi Anadolu'nun en önemli tasavvuf zümrelerinden olan Mevleviler için daha

\footnotetext{
${ }^{164}$ Gordlevski, a.g.e., s. 197.

165 Âşık Paşazade, Osmanoğulları'nın Tarihi, (Haz. K. Yavuz-M. A. Y. Saraç), K Kitaplığı, İstanbul, 2003, s. 97-98; M. Zeki Oral, "Selçukîlerde Giyim Eşyası", Türk Etnografya Dergisi, Say1 V, TTK Basımevi, Ankara, 1963, s. 18.

${ }^{166}$ Süryani Mihail, (çev. H. D. Andreasyan), (Yayınlanmamış TTK nüshası), Ankara, 1944, Fasil XLXIX.

${ }^{167}$ Aksarayî, Müsameratü'l Ahbar ve Müsayeratü’l Ahyar, (çev. M. Öztürk), TTK Yayınevi, Ankara, 2000, s. 264

168 İbn Battuta, I, s. 408.

169 Köprülü, "Bayrak", $\dot{I A}$, II, s. 405.

${ }^{170}$ Pakalın, "Alem" OTDTS, I, s. 48.
} 
ziyade gri ve mavi renklerin ön plana çıkmış olduğu Mevlana'nın bizzat duman rengi (koyu kül rengi) sarkk ve mavi renkli ferace (elbise) tercih etmesinden anlaşılmaktadır. Dahası mavi renk, Mevlevi geleneğinde matemi de karşılamıştır. Eflakî, Mevlana'nın dilinden rüyada mavi ve siyah renkleri görmenin matem ve gama yorumlanması gerektiğini aktarır ${ }^{171}$. Öyle ki; Mevlana öldüğü vakit onun cenaze namazını kıldıran Şerefeddin Keyserî, gökteki meleklerin mavi giyinmiş halde ağladığını görmüş̧ü ${ }^{172}$.

Ortaçağ Türk toplumlarında renklerin paraların adlandırılmasında kullanılması da sıkça karşılaşılan bir durumdur. $\mathrm{Bu}$ bağlamda altın değerindeki paralara sarı, gümüş değerindeki paralara beyaz, bakır değerindeki paralara da kızıl denmekteydi. Anadolu Selçuklu ülkesinde renginden dolayı kızıl ismini almış olan Selçuklu bakır paraları (füls-i ahmer) piyasadaydı. İbn Bibî́173, çeşitli vesilelerle anlattığı olaylarda para yerine kırmızı lira ya da kırmızı dinar tabirini kullanır. Aynı şekilde, 13. yüzyılda ortaya çıkan Akça adını alan beyaz renkli gümüş para da ak renginden dolayı bu ismi almış olduğu, Ermeni müverrih Aknerli Grigor'un, Moğollar döneminde Anadolu'yu anlattığı eserinde geçen kaydından anlaşılmaktadır. Buna göre, Moğol hanı Mengü'nün emriyle memlekette yapılan nüfus sayımından sonra vergi olarak altmış beyaz (yani akçe) alınmışıtır ${ }^{174}$. İbn Bibî de, Erzurum'un Moğollar tarafından ele geçirilmesi bahsini anlatırken Baycu Noyan'ın ağzından şu atasözünü aktarır: Ak akçe kara gün içindir" 175 .

Son olarak, Türk devletlerinde renklerin şahıs isimlerinin önünde sıfat olarak kullanılması (Kara Arslan, Kara Yusuf, Kara Mehmet, Ak Şemseddin, Ak Sungur, Sarı Selim vs.) ya da şehir, dağ, deniz gibi isimlerinin önüne getirilmesi (Kara Amid, Kara Boğdan, Ak-dağ, Kara-müren vs.) de yaygın bir gelenektir. Yukarıda çeşitli vesilelerle belirtildiği üzere bu isimlerin önündeki renk sıfatlarından bazıları gücü, bazıları samimiyeti, bazıları yönü, bazıları ise gerçek manasıyla o ismin rengini temsil etmektedir.

\footnotetext{
${ }^{171}$ Eflakî, C. I, s. 479, C. II, s. 269. Buna göre, diğer renkler arasında kırmızı görmek dirlik ve sevinmeye, yeşil zühte, beyazlık görmek ise takvaya dalalet etmekteydi. Bkz. Aynı Yer.

172 Eflakî, I, s. 370, 453.

173 İbn Bibî, (M. Öztürk), s. 148, 293, 578.

${ }^{174}$ Aknerli Grigor, Moğol Tarihi, (çev. H. D. Andreasyan), İ̈̈EF Yayınları, İstanbul, 1954, s, 24; Tuncer Baykara, Türkiye'nin Sosyal ve İktisadi Tarihi, (XI.-XIV Yüzyll), TDV Yayınları, Ankara, 2000, s. 153

175 İbn Bibî, (M. Öztürk), s. 493.
} 


\section{SONUÇ}

Tarihi süreç içerisinde renkler, birçok devlet ve toplum için çeşitli anlam ve sembolleri karşılamıştır. Renkler, bazen bir devlet, topluluk, zümre veya mezhebi işaret eden bir sembol olarak kullanılırken bazen de bir iletişim aracı olarak kullanılmıştır. İslam ve Türk devletlerinin renk geleneğinde de aynı durumun söz konusu olduğunu söyleyebiliriz. İslamiyet'in doğuşundan başlayarak İslam toplum ve devletleri, sancak, bayrak ve alem gibi unsurlar vesilesiyle renkleri ayırt edici alametler (alamet-i farika) olarak kullanmıştır. Özellikle Dört Halife döneminde başlayan mezhepsel bölünmeler sırasında renkler, farklı mezhep ya da devletlerin sembol unsuru olarak ön plana çıkmış, bu durum Emevi ve Abbasi devletleri döneminde de kesintisiz devam etmiştir. Renklerin birbirine olan zitlığı, (siyah-beyaz ya da ak-kara gibi) çoğu zaman bir muhalefet ve isyan anlamında kullanılmıştır. Mesela, Arap-İslam devletlerinden Abbasiler, beyaz rengi şiar edinmiş olan Emevilere karşı isyan ederken siyah rengi tercih etmişken, Türkmen devletlerinden Akkoyunlu Devleti'nin en büyük rakibi de Kara-koyunlu Devleti olmuştur.

İslam öncesi Orta Asya Türk toplumlarının kendilerine özgü bir renk kültürü olmakla birlikte, bu kültür yaşanılan coğrafya, benimsenen inanç veya siyasi idareden etkilenip tarihi süreç içerisinde farklı boyutlara ulaşabilmiştir. Türkler, İslamiyet'i kabul ettikten sonra Abbasileri de sembolize eden siyah renge daha fazla bağlanmışlar, İslam dünyasının hamisi olduklarını göstermek için hükümdarlar başta olmak üzere siyah elbiseler giymiş, siyah çetr (şemsiye) kullanmış, siyah renkli yüzükler takmışlardır. Bunun yanında sembol olarak farklı renkler de kullanılmıştır. Karahanlıların turuncu bayrak kullanması, Irak Selçuklularının kırmızı rengi tercih etmeleri, Eyyubi ve Memlüklerin sarı rengi kullanmaları gibi.

Özetle renkler, sadece bayraklarda kullanılan ve siyasi anlam ifade eden bir sembol olmayıp İslam/Türk devlet ve toplumlarında zengin bir çerçeve içerisinde kullanılmıştır. Bu sebeple üzüntü ve taziye ifade eden ortamlarda karalar giyilmesi ya da mutluluk ve düğün ortamlarında beyazın saflık ve samimiyet alameti olarak tercih edilmesi gibi günümüze kadar gelmiş olan renklerle ilgili algı ve alışkanlıkların çoğunun, kökenini geçmişten aldığı görülmektedir. Dolayısıyla bu alandaki araştırmaların çeşitlenmesi, İslam ve Türk toplumlarının bu zengin tarihsel geleneğinin ortaya çıkmasına vesile olacağından önem arz etmektedir. 


\section{KAYNAKÇA}

Eskişehir, 1997, s. 297-298.

A Spanish Franciscan, Book of The Knowledge, (Published 1st time: Marcos J. De La Espada, in 1877), (İng. Sir Clements Markham), Hakluyt Society, London, 1912.

Ahmet Cevdet Paşa, Kısas-ı Enbiya ve Tevarih-i Hulefa,(Sad. A. Arslan) C. II, Bedir Yayınevi, İstanbul, 1981.

Ahmet Eflakî, Ariflerin Menkıbeleri, C. I-II, (çev. T. Yazıcı), MEB Yayınevi, İstanbul, 2001.

Aknerli Grigor, Moğol Tarihi, (çev. H. D. Andreasyan), İÜEF Yayınları, İstanbul, 1954.

Aksarayi, Müsameratü’l Ahbar ve Müsayeratü'l Ahyar, (çev. M. Öztürk), TTK Yayınevi, Ankara, 2000.

Alaaddin Ata Melik Cüveynî, Tarih-i Cihangüşa, (Çev. M. Öztürk), C. I, Kültür Bakanlığı Yayınları, Ankara, 1988; İngilizcesi Alâaddin 'Ata-Malik Juvainî, The History Of The World-Conqueror, (Terc. J. A. Boyle), Harvard Universty Press, 1958.

Anonim, Baypars Tarihi, (çev. Ş. Yaltkaya), TTK Yayınevi, Ankara, 2000.

Anonim, Moğolların Gizli Tarihi, (çev. A. Temir), TTK Yayınevi, Ankara, 1995.

Âşık Paşazade, Osmanoğulları'nın Tarihi, (Haz. K. Yavuz-M. A. Y. Saraç), K Kitaplığı, İstanbul, 2003.

BARTHOLD, V. V. Moğol İstilasına Kadar Türkistan, (Haz. H. D. Yıldız), TTK Yay., Ankara, 1990.

BARTHOLD, W., İslam Medeniyeti Tarihi,(Başlangıç, İzah ve Düzeltmeler M. Fuad Köprülü), Diyanet Yayınları, Ankara, 1977.

BAYKARA, Tuncer, Türkiye'nin Sosyal ve Íktisadi Tarihi (XI-XIV. Yüzyll), Ankara, 2000.

BAYRAKTAR, Nesrin, "Kara ve Siyah Renk Adlarının Türkçedeki Kavram ve Anlam Boyutu Üzerine", TÖMER Dil Dergisi, Sayı 126, Ekim-KasımAralık 2004, s. 56-77. 
CAHEN, Claude, Osmanlılardan Önce Anadolu, Tarih Vakfı Yurt Yayınları, Ankara, 2002.

Comnena, (Komnene), The Alexiad, (Edited and translated by Elizabeth A. Dawes), London, 1928.

De GROOT, A. H., "Sandjak-1 Sherif", Encyclopedia of Islam², vol. IX, Leiden, 1997, s. 13-15.

DİVİTÇİOĞLU, Sencer, Kök Türkler (Kut, Küç ve Ülüg), Ada Yayınlanı, İstanbul, 1987.

Ebu Abdullah Muhammed İbn Battuta Tancî, İbn Battuta Seyahatnâmesi, (Çev. A. S. Kazancıgil), C. I. Yapı Kredi Yayınları, İstanbul, 2010.

el-Belazurî, Fütuhu'l Büldan, (çev. M. Fayda), Kültür Bakanlığı Yayınları, Ankara, 2002.

Firdevsî, Şahnâme, (Çev. N. Lugal), Kabalcı Yayınevi, İstanbul, 2005.

GORDLEVSKI, V, Anadolu Selçuklu Devleti, (çev. A. Yaran), Onur Yayınları, Ankara, 1988.

GÜNALTAY, Şemseddin, İslam Tarihinin Kaynaklart, Tarih ve Müverrihler, Endülüs Yayınları, İstanbul, 1991.

Hamdullah Mustawfi-i Qazwinî, Ta'rikh-i Guzida, (Trans. E. G. Browne-R. A. Nicholson), E. J. W. Gibb Memorial, Leiden \& London, 1913.

İbn Bibî, el- Hüseyin b. Muhammed b. Ali el-Caferi er-Rugadi, elEvâmirü'l-Alâ'iyye fi'l Umuri'l-Ala'iyye, (Selçuknâme), (çev. M. Öztürk), II Tercüme, TTK Yayınları, Ankara, 2014

İbn Bibî, Selçuknâme, (çev. M. H. Yinanç), (Haz. Refet Yinanç-Ömer Özkan), Kitabevi Yayınları, İstanbul, 2010.

İbn Fazlan, İbn Fazlan Seyahatnâmesi, (Haz. R. Şeşen), Bedir Yayınevi, Ankara, 1975.

İbn Haldun, Mukaddime, (çev. S. Uludağ), C. I, Dergah Yayınları, İstanbul, 1988 .

İbnu'l Esir, el-Kamil fi't Tarih, (çev. Y. Apaydın-A. Özaydın-A. Ağırakça), C. V, IX,-XII, Bahar Yayınları, İstanbul, 1986-1987.

John of Pian de Carpini, "The Journey (1245-1247)", Contemporaries of Marco Polo, (ed. M. Komroff), Liveright Publising Corp., New York, 1937. 
KAFALI, Mustafa, “Türk Kültüründe Renkler” Yörtürk Dergisi (Mart-Nisan 2002), Say1 42, s. 39-41.

KAFESOĞLU, İbrahim Türk Millî Kültürü̈, Boğaziçi Yayınları, İstanbul, 1984.

KÖPRÜLÜ, M. Fuad, "Bayrak", İslam Ansiklopedisi, C. II, MEB Yayınevi, Eskişehir, 1977, s. 401-420.

KÖPRÜLÜ, M. Fuad, Türkiye Tarihi, Akçağ Yayınları, Ankara, 2005.

LEWIS, Bernard, “Abbasids”, Encyclopedia of Islam², vol. I, Leiden, 1986, s. 15-23.

LIGETI, L., Bilinmeyen İç Asya, (Çev. S. Karatay), C. I-II, MEB Yayınevi, İstanbul, 1991.

Marco Polo, The Travels of Marco Polo, (İng. Çev. H. Murray), Oliver and Boyd, Tweeddale Court, Edingburg, 1845.

MERÇiL, Erdoğan, Selçuklular'da Hükümdarlık Alâmetleri, TTK Yayınları, Ankara, 2007.

MEVDUDÎ, Selçuklular Tarihi, (çev. A. Genceli), Hilal Yayınları, İstanbul, 1971.

Nizamülmülk, Siyasetnâme, (Haz. S. Yalsızuçanlar), Lacivert Yayıncılık, İstanbul, 2007.

ORAL, M. Zeki, "Selçukîlerde Giyim Eşyası", Türk Etnografya Dergisi, Sayı V, TTK Basımevi, Ankara, 1963, s. 14-20.

ÖGEL, Bahaeddin, Türk Kültürünün Gelişme Çağları, C. II, MEB Yayınevi, İstanbul, 2001.

ÖZ, Mustafa, "Mukanna el-Horasânî”, Diyanet İslam Ansiklopedisi, C. 31, Diyanet Yayınları, İstanbul, 2006, s. 124-125.

PAKALIN, Zeki, “Alem” Osmanlı Tarih Deyimleri ve Terimleri Sözlüğ̈̈, C. I, İstanbul, 1993, MEB Yayınevi, s. 47-49.

Ravendî, Muhammed b. Ali b. Süleyman, Râhat-üs-Südûr ve Âyet-üs Sürûr,(Gönüllerin Rahatı ve Sevinç Alameti), (çev. A. Ateş), C. II, TTK Yayınları, Ankara, 1999.

Sadruddin Ebu'l Hasan Ali İbn Nasir İbn Ali el-Hüseyni, Ahbarü'dDevleti's-Selçukiyye, (çev. N. Lugal), TTK Yayınları, Ankara, 1999. 
SÜMER, Faruk, "Oğuzlar", İslam Ansiklopedisi, C. IX, MEB Yayınevi, Eskişehir, 1997.

Sıbt İbnu'l Cevzî, Miratü'z Zaman fi Tarihi'l Ayan'da Selçuklular, (Seçme, Tercüme ve Değerlendirme Ali Sevim), TTK Yay., Ankara, 2011.

Süryani Mihail, (çev. H. D. Andreasyan), (Yayınlanmamış TTK nüshası), Ankara, 1944.

Şemseddin Samî, Kamus-ı Türkî, Çağrı Yayınları, İstanbul, 1996.

TANERİ, Aydın, Celaluddin Harizmşah ve Zamanı, Kültür Bakanlığı Yayınları, Ankara, 1977.

TANERİ, Aydın, "Çetr", Diyanet İslam Ansiklopedisi, C. 8, Ankara, 1993, s. 293-294.

TURAN, Osman, Selçuklular ve Türk İslam Medeniyeti, Boğaziçi Yayınları, İstanbul, 1998.

TURAN, Osman, Selçuklular Zamanında Türkiye, Boğaziçi Yayınları, İstanbul, 1996.

TURAN, Osman, Türk Cihan Hâkimiyeti Mefkûresi Tarihi, C. I, Boğaziçi Yayınları, İstanbul, 1998.

TURAN, Osman, Türkiye Selçukluları Hakkında Resmi Vesikalar (Metin, Tercüme ve Araştırmalar), TTK Yayınevi, Ankara, 1988.

UZUNÇARŞILI, İ. Hakkı, Osmanlı Devlet Teşkilatına Medhal, TTK Yayınevi, Ankara, 1988.

WELlHAUSEN, J., Arab Devleti ve Sükutu, (çev. F. Iş1ltan), Ankara Üniversitesi Basımevi, Ankara, 1963.

YALTKAYA, Şerafeddin, "Tarihte Renk", Türkiyat Mecmuası, C. VII-VIII, İstanbul, 1942, s. 41-47.

Yusuf Has Hacib, Kutadgu Bilig, C. I, (Metin R. Rahmeti Arat), TDK Yayınları, Ankara, 1999.

YİNANÇ, M. Halil, "Akkoyunlular”, İslam Ansiklopedisi, C. I, MEB Yayınevi, Eskişehir, 1997.

ZEYDAN, Corci, Íslam Medeniyeti Tarihi, , (çev. N. Gök), İletişim Yayınları, İstanbul, 2004. 